\title{
Combustion smoke-induced inflammation in the olfactory bulb of adult rats
}

\author{
Ying-Ying Zou ${ }^{1+}$, Yun Yuan ${ }^{2+}$, Enci Mary Kan ${ }^{3}$, Jia Lü ${ }^{3,4^{*}}$ and Eng-Ang Ling ${ }^{4^{*}}$
}

\begin{abstract}
Background: The damaging effect of combustion smoke inhalation on the lung is widely reported but information on its effects on the olfactory bulb is lacking. This study sought to determine the effects of smoke inhalation on the olfactory bulb, whose afferent input neurons in the nasal mucosa are directly exposed to external stimuli, such as smoke.

Methods: Adult male Sprague-Dawley rats were subjected to combustion smoke inhalation and sacrificed at different time points. Changes in olfactory bulb proteins including vascular endothelial growth factor (VEGF), inducible nitric oxide synthase (iNOS), endothelial nitric oxide synthase (eNOS), neuronal nitric oxide synthase (nNOS), $\mathrm{Na}^{+}-\mathrm{K}^{+}-\mathrm{Cl}^{-}$ cotransporter 1 (NKCC1), glial fibrillary acidic protein (GFAP), and aquaporin-4 (AQP4) were evaluated by Western blot analysis. In addition, ELISA was conducted for cytokine and chemokine levels, and double immunofluorescence labeling was carried out for GFAPNEGF, GFAP/AQP4, NeuN/nNOS, GFAP/NKCC1, NeuN/NKCC1, GFAP/Rhodamine isothiocyanate (RITC), and transferase dUTP nick end labeling (TUNEL). Aminoguanidine was administered to determine the effects of iNOS inhibition on the targets probed after smoke inhalation.

Results: The results showed a significant increase in VEGF, iNOS, eNOS, nNOS, NKCC1, and GFAP expression in the bulb tissues, with corresponding increases in inflammatory cytokines and chemokines after smoke inhalation. Concurrent to this was a drastic increase in AQP4 expression and RITC permeability. Aminoguanidine administration decreased the expression of iNOS and RITC extravasation after smoke inhalation. This was coupled with a significant reduction in incidence of TUNEL + cells that was not altered with administration of L-NG-nitroarginine methyl ester (L-NAME).
\end{abstract}

Conclusions: These findings suggest that the upregulation of iNOS in response to smoke inhalation plays a major role in the olfactory bulb inflammatory pathophysiology, along with a concomitant increase in pro-inflammatory molecules, vascular permeability, and edema. Overall, these findings indicate that the olfactory bulb is vulnerable to smoke inhalation.

Keywords: edema, inflammation, nitric oxide synthase, olfactory bulb, smoke

\section{Background}

Smell is a major sensory function and plays an important role in identification, alarm, appetite, and mood [1]; it is mediated by the olfactory bulb. The olfactory bulb participates in many physiological functions, such as appetite regulation, lactation, response to adverse environments, and social interaction [2,3]. It contains a large number of afferent input sensory cells that might be

\footnotetext{
*Correspondence: ljia@dso.org.sg; antlea@nus.edu.sg

${ }^{\dagger}$ Equal contributors

${ }^{3}$ Defense Medical and Environmental Research Institute, DSO National Laboratories, 27 Medical Drive, Singapore 117510, Singapore

${ }^{4}$ Department of Anatomy, Yong Loo Lin School of Medicine, National University of Singapore, 4 Medical Drive, MD10, Singapore 117597, Singapore Full list of author information is available at the end of the article
}

directly exposed to undesirable external stimuli, such as smoke; hence, damage to the olfactory bulb from smoke inhalation could affect the noted functions.

Smoke inhalation injury occurs from the inhalation of the by-products of combustion, which includes toxic gases, such as carbon monoxide and cyanide, and particulate matter [4-6]. The damaging effects of smoke inhalation on the pulmonary system are widely reported, with most of the current literature focused on the management of acute smoke inhalation-induced damage on the respiratory system [7]. Smoke inhalation injury has been reported to lead to a $20 \%$ increase in mortality in burn patients. In conjunction with such comorbidities as pneumonia, mortality can further increase by up to $60 \%$ 
[8]. The effects of smoke inhalation on the central nervous system are less well researched, and indeed, even more so regarding the olfactory bulb [9-13].

We reported previously that the acute inhalation of combustion smoke caused pathologic changes in the adult rat retina, cerebellum, and hippocampus, which were attributed to increased vascular permeability and edema $[12,13]$. Here we have extended our study by investigating changes in the olfactory bulb of the adult rat subjected to a similar smoke challenge. Combustion smoke is known to result in a hypoxic environment consisting of elevated carbon monoxide and decreased oxygen. So far, there have been limited studies reporting injury to the olfactory bulb as a result of hypoxia [14-16]. As far as can be ascertained, there is no available literature on the effects of combustion smoke inhalation on the olfactory bulb. Therefore, this study was designed to determine whether the neurons or glial cells of the olfactory bulb would also be affected by combustion smoke inhalation.

In view of the fact that inflammatory mediators, such as TNF- $\alpha$, interleukin-1 $\beta$ (IL-1 $\beta)$, glutamate, nitric oxide synthase (NOS), vascular endothelial growth factor (VEGF), glial fibrillary acidic protein (GFAP), $\mathrm{Na}^{+}-\mathrm{K}^{+}-\mathrm{Cl}^{-}$ cotransporter 1 (NKCC1), and aquaporin-4 (AQP4), are altered in brain injuries [13,17-19], it was surmised that these molecular biomarkers in the olfactory bulb might also be affected following combustion smoke inhalation. Hence, we sought to determine whether these protein markers in the olfactory bulb would be altered as a result of smoke inhalation.

\section{Methods}

Animals

A total of 155 adult male Sprague-Dawley rats (body weight 280 to $320 \mathrm{~g}$, ages 6 to 8 weeks) were used. All experiments were carried out in accordance with the National Institute of Health Guide for the Care and Use of Laboratory Animals (NIH Publications No. 80-23). The project was approved by the Institutional Animal Care and Use Committee (IACUC), DSO National Laboratories (Protocol Number: 09/87) and the National University of Singapore (Protocol 088/07). All efforts were made to minimize the number of rats used, as well as stress and suffering. The rats were randomly divided into normal control $(C)$, smoke inhalation plus saline $(S I+S)$, smoke inhalation + aminoguanidine (SI + AG) and smoke inhalation + NG nitro L arginine methyl ester (SI + L-NAME) groups. Table 1 shows the number of animals used for smoke challenge, drug intervention, and the various tests investigated.

\section{Smoke challenge}

The entire smoke inhalation testing set-up was designed with reference to Lee et al. (2005) [9] and Whitehead et al. (2003) [6] and was adopted by us previously [12]. Briefly, the revised set-up was designed and built to achieve a constant smoke challenge of constant smoke toxicants from burning cotton. The set-up consists of three main parts: a furnace, an equilibrium chamber to contain the volume of smoke being generated by the furnace, and animal exposure chambers. Smoke was

Table 1 Number of rats used in different experiments

\begin{tabular}{|c|c|c|c|c|c|c|c|c|}
\hline & Control & $0.5 \mathrm{~h}$ & $3 \mathrm{~h}$ & $24 \mathrm{~h}$ & $72 \mathrm{~h}$ & Day 7 & Day 14 & Total \\
\hline \multirow[t]{2}{*}{ Inflammatory cytokines assay } & 3 & & & $\mathrm{SI}+\mathrm{S} 3$ & & & & 9 \\
\hline & & & & $\mathrm{SI}+\mathrm{AG} 3$ & & & & \\
\hline \multirow[t]{2}{*}{ Western blotting } & 4 & $\mathrm{SI}+\mathrm{S} 4$ & +54 & $\mathrm{SI}+\mathrm{S} 4$ & $\mathrm{SI}+\mathrm{S} 4$ & & & 28 \\
\hline & & & & $\mathrm{SI}+\mathrm{AG} 4$ & $\mathrm{SI}+\mathrm{AG} 4$ & & & \\
\hline \multirow[t]{2}{*}{ Double immunofluorescence } & 4 & & & $\mathrm{SI}+\mathrm{S} 4$ & $\mathrm{SI}+\mathrm{S} 4$ & $+\mathrm{S} 4$ & +54 & 28 \\
\hline & & & & $\mathrm{SI}+\mathrm{AG} 4$ & $\mathrm{SI}+\mathrm{AG} 4$ & & & \\
\hline \multirow[t]{4}{*}{ Nitrite assay } & 4 & $\mathrm{SI}+\mathrm{S} 4$ & $\mathrm{SI}+\mathrm{S} 4$ & $\mathrm{SI}+\mathrm{S} 4$ & $\mathrm{SI}+\mathrm{S} 4$ & & & 44 \\
\hline & & & & $\mathrm{SI}+\mathrm{AG} 4$ & $\mathrm{SI}+\mathrm{AG} 4$ & & & \\
\hline & & & $\mathrm{SI}+\mathrm{AG} 4$ & $\mathrm{SI}+\mathrm{N} 4$ & $\mathrm{SI}+\mathrm{N} 4$ & & & \\
\hline & & & $\mathrm{SI}+\mathrm{N} 4$ & & & & & \\
\hline \multirow[t]{2}{*}{ Glutamate assay } & 4 & $\mathrm{SI}+\mathrm{S} 4$ & $\mathrm{SI}+\mathrm{S} 4$ & $\mathrm{SI}+\mathrm{S} 4$ & $\mathrm{SI}+\mathrm{S} 4$ & & & 28 \\
\hline & & & & $\mathrm{SI}+\mathrm{AG} 4$ & $\mathrm{SI}+\mathrm{AG} 4$ & & & \\
\hline \multirow[t]{2}{*}{ Assessment of vascular permeability } & 3 & & & $\mathrm{SI}+\mathrm{S} 3$ & & & & 9 \\
\hline & & & & $\mathrm{SI}+\mathrm{AG} 3$ & & & & \\
\hline \multirow[t]{2}{*}{ Detection of apoptosis } & 3 & & & & $\mathrm{SI}+\mathrm{S} 3$ & & & 9 \\
\hline & & & & & $\mathrm{SI}+\mathrm{AG} 3$ & & & \\
\hline Total & & & & & & & & 155 \\
\hline
\end{tabular}

$\mathrm{SI}+\mathrm{AG}$, smoke inhalation plus aminoguanidine; $\mathrm{SI}+\mathrm{N}$, smoke inhalation plus L-NAME; $\mathrm{SI}+\mathrm{S}$, smoke inhalation plus saline. 
generated by burning $33 \mathrm{~g}$ of cotton towel in a $290^{\circ} \mathrm{C}$ furnace for $5 \mathrm{~min}$ and then allowed to collect and cool in the equilibrium chamber. Unanesthetized awake animals were placed individually in up to two exposure chambers and allowed to acclimatize for $15 \mathrm{~min}$ before release of the smoke from the equilibrium chamber. The animals were exposed to the smoke mixture for $60 \mathrm{~min}$. Gas concentration was monitored by a carbon monoxide and oxygen combustion meter (Testo AG, Lenz-kirch, Germany). In this experimental paradigm, we have established that the following smoke challenge conditions would result in an approximate mortality rate of 10\%: CO level, 2,200 to $2,500 \mathrm{ppm} ; \mathrm{O}_{2}$ level, $>19 \%$. Fresh air was allowed to recirculate into the test chambers if either the $\mathrm{CO}$ level reached over 2,500 ppm or the $\mathrm{O}_{2}$ level dropped below $19 \%$, to prevent death from hypoxia or CO-poisoning. Normal control rats were not subjected to smoke inhalation.

\section{Drug administration}

The rats were given intraperitoneal injections of aminoguanidine (100 mg/kg of body weight; Sigma, St Louis, MO, USA) [20] or L-NAME (300 mg/ $\mathrm{kg}$ of body weight; Sigma) [21], with the first injection given immediately after smoke inhalation, followed by an injection every 24 $\mathrm{h}$ until the respective harvest time points. The $\mathrm{SI}+\mathrm{S}$ group received an intraperitoneal injection of an equal volume of saline after smoke inhalation. Fresh olfactory bulbs were removed at the time of sacrifice and prepared for Western blotting analysis and measurement of nitric oxide production. In parallel to this, another group of rats was examined for vascular permeability changes in the olfactory bulb following SI + S and SI + AG.

\section{Inflammatory cytokine assay}

The relative protein concentrations of 12 pro-inflammatory cytokines to control samples in the protein supernatant from the olfactory bulb tissue lysate of rats subjected to combustion smoke inhalation $(n=3$ at $24 \mathrm{~h}$ after smoke inhalation) were determined with a Rat Inflammatory
Cytokines Multi-Analyte ELISArray kit (Mer004A; Qiagen, Valencia, CA, USA). The tissue homogenates for the ELISArray measurements were prepared as for Western blotting and ELISArray measurements were performed according to the manufacturer's protocol.

\section{Western blotting analysis}

At designated time points after smoke inhalation, the rats were anesthetized with ketamine $(75 \mathrm{mg} / \mathrm{kg})$ and xylazine (10 mg/kg) intraperitoneally and were sacrificed by cardiac puncture. After sacrifice, fresh olfactory bulb tissue from the $\mathrm{C}(n=4), \mathrm{SI}+\mathrm{S}(n=4$ each at $0.5,3,24$, and $72 \mathrm{~h}$ after smoke inhalation) and SI + AG ( $n=4$ each at 24 and $72 \mathrm{~h}$ after smoke inhalation) groups were removed and were snap-frozen in liquid nitrogen and stored at $-80^{\circ} \mathrm{C}$. The olfactory bulb tissue proteins were extracted using a protein extraction kit (Pierce Biotechnology, Inc., Rockford, IL, USA) containing protease inhibitors. All procedures were carried out at $4^{\circ} \mathrm{C}$. Homogenates were centrifuged at $15,000 \mathrm{~g}$ for $15 \mathrm{~min}$ and the supernatant collected. The protein concentration of the samples was determined by the Bradford method using BSA (Bio-Rad Laboratories, Hercules, CA, USA). Samples of supernatants containing $35 \mathrm{mg}$ of protein were heated to $95^{\circ} \mathrm{C}$ for $5 \mathrm{~min}$ and were separated on $8 \%$ sodium dodecyl sulphate-polyacrylamide gels (for inducible NOS (iNOS), neuronal NOS (nNOS), endothelial NOS (eNOS), and NKCC1), and 12\% sodium dodecyl sulphate-polyacrylamide gels (for GFAP, VEGF, and AQP4) using a Mini Protein II apparatus (Bio-Rad Laboratories). Protein bands were electroblotted onto 0.45 mm polyvinylidene difluoride membranes (Bio-Rad Laboratories) using a semidry electrophoretic transfer cell. The membranes were washed with Tris-buffered saline (TBS) $-0.1 \%$ Tween buffer and then blocked with $5 \% \mathrm{w} / \mathrm{v}$ non-fat dry skim milk for $60 \mathrm{~min}$ at room temperature. After this, they were incubated with primary antibodies (Table 2) in blocking solution overnight on a shaker at $4^{\circ} \mathrm{C}$. After rinsing with TBS-0.1\% Tween, the membranes were incubated with horseradish peroxidase-conjugated secondary antibody (1:2,000 to 10,000; Pierce Biotechnology,

Table 2 Primary antibodies used in Western blotting analysis

\begin{tabular}{lll}
\hline Name & Dilution & Source \\
\hline AQP4 & $1: 2,500$ & Santa Cruz Biotechnology, Inc., CA, USA \\
VEGF & $1: 500$ & Santa Cruz Biotechnology, Inc. CA, USA \\
iNOS & $1: 2,500$ & BD Biosciences, CA, USA \\
nNOS & $1: 500$ & BD Biosciences, CA, USA \\
eNOS & $1: 500$ & BD Biosciences, CA, USA \\
GFAP & $1: 1,000$ & Millipore Corporation, Bioscience, Billerica, MA, USA \\
NKCC1 & $1: 500$ & Millipore Corporation, Bioscience, Billerica, MA, USA \\
B-actin & $1: 10,000$ & Sigma, MO, USA
\end{tabular}

AQP4, aquaporin-4; eNOS, endothelial nitric oxide synthase; GFAP, glial fibrillary acidic protein; iNOS, inducible nitric oxide synthase; $\mathrm{NKCC1} \mathrm{Na}^{+}-\mathrm{K}^{+}-\mathrm{Cl}^{-}$ cotransporter 1; nNOS, neuronal nitric oxide synthase; VEGF, vascular endothelial growth factor. 
Inc.) for $1 \mathrm{~h}$. Proteins were revealed by an enhancedchemiluminescence detection system according to the manufacturer's instruction (Super Signal West Pico Horseradish Peroxidase detection kit; Pierce Biotechnology, Inc.) and developed on film. The band intensity of target protein levels relative to the housekeeping protein, $\beta$-actin, was quantified using the scanning densitometer and Quantity One Software, version 4.4.1 (Bio-Rad Laboratories).

\section{Double immunofluorescence}

The $\mathrm{C}(n=4), \mathrm{SI}+\mathrm{S}(n=4$ each at $24,72 \mathrm{~h}, 7$ days, and 2 weeks after smoke inhalation) and SI + AG ( $n=4$ each at 24 and $72 \mathrm{~h}$ after smoke inhalation) groups were used for immunofluorescence studies. These time points were chosen because Western blotting analysis showed obvious changes in the inflammatory targets of interest in the levels following smoke inhalation over this period. At the designated time points, the rats were anesthetized with intraperitoneal ketamine $(75 \mathrm{mg} / \mathrm{kg})$ and xylazine $(10 \mathrm{mg} /$ $\mathrm{kg}$ ) and then perfused transcardially with saline, followed by $2 \%$ paraformaldehyde in $0.1 \mathrm{M}$ phosphate buffer. The olfactory bulbs were removed, post-fixed for $2 \mathrm{~h}$ in the same fixative, then cryoprotected in $15 \%$ sucrose for 24 to $48 \mathrm{~h}$. Frozen coronal sections, $35 \mu \mathrm{m}$ thick, were cut with a cryostat (Leica CM 3050), mounted onto gelatin-coated microscopic slides, and stored at $-20^{\circ} \mathrm{C}$ until use. Tissue sections at different time points were incubated in primary antibodies (Table 3). After incubation, FITC-conjugated and Cy3-conjugated secondary antibodies were added. Images representing at least one brain bulb each from four rats at different time points were captured under a confocal microscope (Olympus Fluoview TM1000). Immunofluorescence labeling for the various antibodies directed against the respective cell types was consistent and reproducible across different rats.

\section{Nitrite assay}

The total amount of $\mathrm{NO}(\mu \mathrm{M})$ in the olfactory bulb samples from the $C(n=4), S I+S(n=4$ each at $0.5,3,24$, and $72 \mathrm{~h}$ after smoke inhalation), SI + AG, and SI + L-NAME ( $n=4$ each at 3,24 , and $72 \mathrm{~h}$ after smoke inhalation) groups was assessed by the Griess reaction, using a colorimetric assay kit (US Biological, Swampscott, MA, USA) that detects nitrite. Homogenates and supernatant, as described for Western blotting, were prepared for $\mathrm{NO}^{2-}$ measurements. Briefly, $85 \mu \mathrm{l}$ of each sample was added to $5 \mu \mathrm{l}$ of nitrate reductase followed by $5 \mu \mathrm{l}$ enzyme cofactor according to the manufacturer's instructions and incubated for $1 \mathrm{~h}$ at room temperature. Next, $5 \mu \mathrm{l}$ of enhancer was added and this was incubated for $10 \mathrm{~min}$. Following this, $50 \mu \mathrm{l}$ of Griess reagent $\mathrm{R} 1$ and $50 \mu \mathrm{l}$ of Griess reagent R2 were added to the solution and the color was allowed to develop at room temperature for $10 \mathrm{~min}$. The optical density of the samples was measured at $540 \mathrm{~nm}$ using the GENios microplate reader (Tecan Austria GmbH, Salzburg, Austria). Nitrite concentration was determined using a nitrite standard curve.

\section{Glutamate assay}

The glutamate concentrations $(\mathrm{mg} / \mathrm{ml})$ in the olfactory bulb protein supernatant from the $\mathrm{C}(n=4), \mathrm{SI}+\mathrm{S}(n=4$ each at $0.5,3,24$, and $72 \mathrm{~h}$ after smoke inhalation) and $\mathrm{SI}+\mathrm{AG}$ ( $n=4$ each at 24 and $72 \mathrm{~h}$ after smoke inhalation) groups were determined using a Glutamate BioAssay kit (US Biological, Swampscott, MA, USA; catalog number G7114). The protein lysates were prepared as for Western blotting and the bioassay measurements were performed according to the manufacturer's protocol.

\section{Assessment of vascular permeability}

Rhodamine isothiocyanate (RITC, molecular weight = 536.08) (Sigma, MO, USA) was used as a fluorescent tracer to evaluate vascular permeability. The $\mathrm{C}, \mathrm{SI}+\mathrm{S}$, and $\mathrm{SI}+\mathrm{AG}$ groups ( $n=3$ per group) were given an intraperitoneal injection of RITC (5 $\mu \mathrm{l}$ of $1 \% \mathrm{RITC} / \mathrm{g}$ body weight) dissolved in normal saline. The RITC was administered to rats $24 \mathrm{~h}$ after smoke inhalation. This time point was chosen because immunofluorescence and Western blot analysis showed obvious changes in the olfactory bulb following smoke inhalation over this period. The rats were sacrificed at $3 \mathrm{~h}$ after RITC administration. Following perfusion with 2\% paraformaldehyde in $0.1 \mathrm{M}$ phosphate buffer, the

\section{Table 3 Primary antibodies used in immunofluorescence studies}

\begin{tabular}{llll}
\hline Name & Dilution & Source & Catalog number \\
\hline AQP4 & $1: 250$ & Santa Cruz Biotechnology, Inc., CA, USA & SC-20978 \\
VEGF & $1: 100$ & Santa Cruz Biotechnology, Inc. CA, USA & $222-P$ \\
GFAP & $1: 500$ & Millipore Corporation, Bioscience, Billerica, MA, USA & MAB360 \\
NKCC1 & $1: 200$ & Millipore Corporation, Bioscience, Billerica, MA, USA & AB3560P \\
nNOS & $1: 200$ & BD Biosciences, CA, USA & 610311 \\
NeuN & $1: 500$ & Abcam, Cambridge, MA, USA & ab177487
\end{tabular}

AQP4, aquaporin-4; GFAP, glial fibrillary acidic protein; $\mathrm{NKCC1}, \mathrm{Na}^{+}-\mathrm{K}^{+}-\mathrm{Cl}^{-}$cotransporter 1; nNOS, neuronal nitric oxide synthase; VEGF, vascular endothelial growth factor. 
olfactory bulbs were removed and frozen coronal sections, $35 \mu \mathrm{m}$ thick, were cut and processed, as described previously. Immunofluorescence labeling was carried out using GFAP antibody (Millipore Corporation, Bioscience, Billerica, Massachusetts, USA), following the same method as for double immunofluorescence labeling.

\section{Detection of apoptosis}

To detect cells undergoing apoptosis in the olfactory bulb, frozen sections as for double immunofluorescence labeling were derived from the $\mathrm{C}(n=3), \mathrm{SI}+\mathrm{S}(n=3$ at $72 \mathrm{~h}$ after smoke inhalation), and SI + AG ( $n=3$ at $72 \mathrm{~h}$ after smoke inhalation) groups were assessed using a terminal deoxynucleotidyl transferase dUTP nick end labeling (TUNEL) apoptosis detection kit (Millipore Corporation, Bioscience, Billerica, Massachusetts, USA). The frozen sections were fixed with 4\% paraformaldehyde in $0.1 \mathrm{M}$ phosphate buffer, $\mathrm{pH} 7.4$, and subsequently washed with three lots of PBS for 10 min, permeabilized with $0.2 \%$ Triton-X100 in PBS twice for $10 \mathrm{~min}$ at room temperature, and subsequently washed three times with $\mathrm{PBS}$ for $5 \mathrm{~min}$ at $37^{\circ} \mathrm{C}$. The remaining steps were performed according to the manufacturer's instructions. The sections were counterstained with 4',6diamidino-2-phenylindole (DAPI), washed with PBS, and mounted with a fluorescent mounting medium (Dako Cytomation, Glostrup, Denmark). TUNEL-positive cells were enumerated by counting the labeled cells in eight randomly selected microscopic fields obtained from each specimen at $40 \times$ and $80 \times$ magnification. The percentage of TUNEL-positive cells was calculated and averaged.

\section{Statistical analysis}

For Western blots and multi-analyte ELISArray, data are reported as mean \pm standard deviation. Data were analyzed using one-way ANOVA followed by post-hoc analysis using Dunnet's test (SPSS version 15.0 software, Chicago, IL, USA) to determine the statistical significance of differences between the $\mathrm{C}, \mathrm{SI}+\mathrm{S}, \mathrm{SI}+\mathrm{AG}$, and $\mathrm{SI}+\mathrm{L}-\mathrm{NAME}$ groups. All experiments were conducted in triplicate from different tissue samples. Significance is accepted as $P<0.05$ and is denoted by an asterisk (* $P<0.05$; * $P<0.01)$.

\section{Results}

\section{Normal histology of the olfactory bulb}

With $\mathrm{H}$ \& E staining, the olfactory bulb showed six well delineated layers, namely, the nerve fiber layer, glomerular layer, external plexiform layer, mitral cell layer, internal plexiform layer, and granule cell layer (Figure 1). In response to blood gas changes, as previously reported [12], reactive alterations were observed affecting glial reactions and expression of cytokines and chemokines in bulb tissue protein extracted in toto. The following immunofluorescence observations were focused mainly on

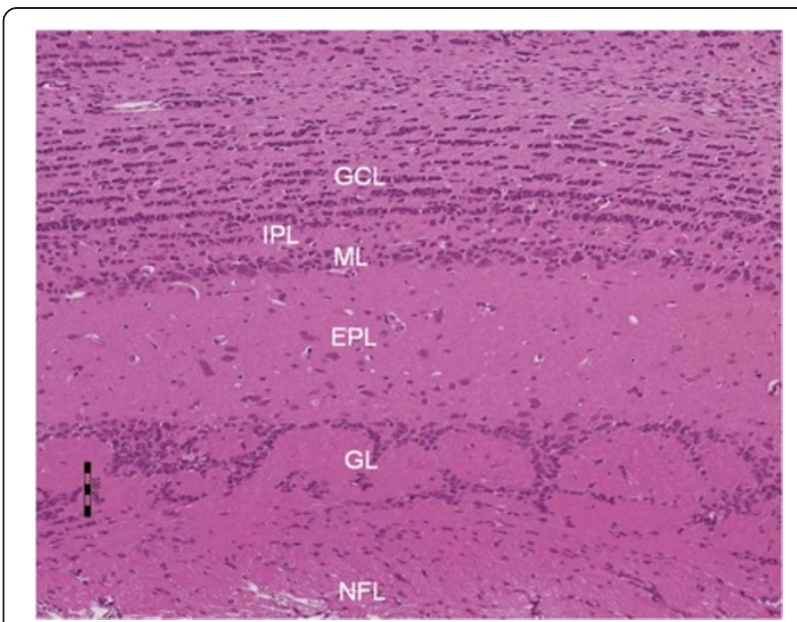

Figure $1 \mathrm{H}$ \& E staining of normal olfactory bulb tissue. The olfactory bulb shows six well delineated layers, namely, the nerve fiber layer (NFL), glomerular layer (GL), external plexiform layer $(E P L)$, mitral cell layer $(\mathrm{ML})$, internal plexiform layer (IPL), and granule cell layer (GCL). Scale bar $=100.0 \mu \mathrm{m}$.

reactive changes due to smoke inhalation in the external plexiform layer, mitral cell layer, and internal plexiform layer.

\section{Elevated inflammatory cytokines after smoke inhalation}

In the olfactory bulb tissue, the concentration levels of the cytokines IL-1 $\alpha$, IL-1 $\beta$, IL-2, IL-4, IL-6, IL-10, IL-12, IL-13, IFN- $\gamma$, TNF- $\alpha$, GM-CSF, and RANTES were increased significantly at $24 \mathrm{~h}$ in the $\mathrm{SI}+\mathrm{S}$ group when compared with the matched control (Figure 2). In particular, the increase was most significant $(P<0.01)$ for IL-12, IFN- $\gamma$, and TNF- $\alpha$ in the SI $+S$ group, as compared with the matched control. Administration of aminoguanidine significantly decreased the expression levels of IL-1 $\alpha$, IL-1 $\beta$, IL-12, and TNF- $\alpha$, compared with the $\mathrm{SI}+\mathrm{S}$ group at $24 \mathrm{~h}$ (Figure 2 ).

\section{Western blotting analysis}

By Western blotting analysis, the olfactory bulb tissue showed a progressive and significant increase in protein levels of VEGF, AQP4, GFAP, NKCC1, iNOS, eNOS, and nNOS over time in SI $+S$ group (Figures 3 and 4 ). Densitometry analysis of the VEGF-immunoreactive band of approximately $21 \mathrm{kDa}$ showed a significant increase at $3 \mathrm{~h}(P<0.01), 24 \mathrm{~h}(\mathrm{Pp}<0.01)$, and $72 \mathrm{~h}$ $(P<0.05)$ in the $\mathrm{SI}+\mathrm{S}$ group, as compared with that of the $C$ group (Figure $3 \mathrm{~A}, \mathrm{~B}$ ). In the $\mathrm{SI}+\mathrm{AG}$ group, the VEGF protein expression level remained relatively unaltered at 24 and $72 \mathrm{~h}$ compared with the $\mathrm{SI}+\mathrm{S}$ group (without aminoguanidine treatment) (Figure 3A,B).

AQP4 was detected as a major band at approximately $34 \mathrm{kDa}$, and showed a significant increase in optical density in the SI $+\mathrm{S}$ group at $0.5,3,24$, and $72 \mathrm{~h}$ 


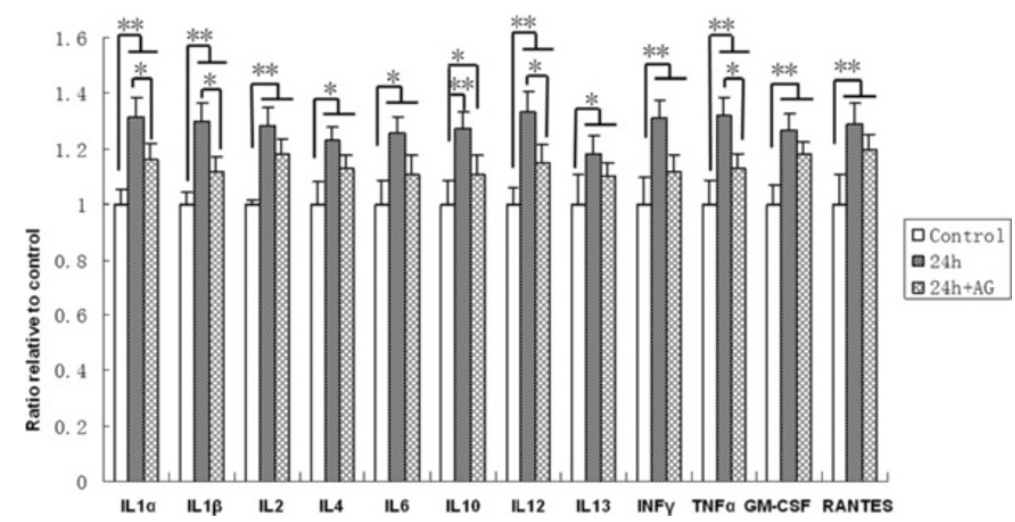

Figure 2 Elevated cytokines and chemokines. The concentration levels of the various cytokines IL-1a, IL-1ß, IL-2, IL-4, IL-6, IL-10, IL-12, IL-13, IFNTNF-a, GM-CSF, and RANTES are increased significantly at $24 \mathrm{~h}$ in the $\mathrm{SI}+\mathrm{S}$ group, as compared with matched controls. The increase was most substantial for IL-12, IFN- $\gamma$ and TNF-a in the SI + S group, compared with the matched control. In the SI + AG group, the levels of IL-1a, IL-1ß, IL-12, and TNF-a were significantly decreased compared with the $\mathrm{SI}+\mathrm{S}$ group. ${ }^{*} P<0.05$; ${ }^{* *} P<0.01$.

$(P<0.05)$ in comparison with control levels (Figure 3A,C). Administration of aminoguanidine $(\mathrm{SI}+\mathrm{AG})$ did not affect AQP4 optical density compared with the SI $+\mathrm{S}$ group at 24 and $72 \mathrm{~h}$.

GFAP was detected as a major band at approximately $45 \mathrm{kDa}$. In the $\mathrm{SI}+\mathrm{S}$ group, GFAP protein expression level was significantly increased at 24 and $72 \mathrm{~h}(P<0.05)$, compared with the $\mathrm{C}$ group (Figure $3 \mathrm{~A}, \mathrm{D}$ ). In the $\mathrm{SI}+$ AG group, GFAP protein expression level was significantly decreased at $72 \mathrm{~h}$, compared with the $\mathrm{SI}+\mathrm{S}$ group (Figure 3A,D).

NKCC1 was detected as a major band at approximately $170 \mathrm{kDa}$. In the SI + S group, the NKCC1 protein expression level showed a substantial increase at $24 \mathrm{~h}$ $(P<0.01)$, compared with the $\mathrm{C}$ group (Figure $3 \mathrm{~A}, \mathrm{E})$. The NKCC1 protein expression level in the $\mathrm{SI}+\mathrm{S}$ group appeared to decline at $0.5 \mathrm{~h}$, compared with the $\mathrm{C}$ group (Figure 3A,E). Aminoguanidine administration did not affect the expression level of NKCC1.

The iNOS immunoreactive bands, with a molecular weight of approximately $130 \mathrm{kDa}$, increased significantly in optical density from 3 to $72 \mathrm{~h}(P<0.05, P<0.01, P<0.01$, respectively) in the $\mathrm{SI}+\mathrm{S}$ group, compared with the $\mathrm{C}$ group levels (Figure 4A,B). In the SI + AG group at 24 and $72 \mathrm{~h}$, iNOS protein expression level was decreased significantly $(P<0.05)$, as compared with the $\mathrm{SI}+\mathrm{S}$ group at the same time points (Figure $4 \mathrm{~A}, \mathrm{~B}$ ).

The eNOS immunoreactive bands, with a molecular weight of approximately $140 \mathrm{kDa}$, increased significantly in optical density in the $\mathrm{SI}+\mathrm{S}$ group at 24 and $72 \mathrm{~h}(P<0.05)$ compared with the $C$ group levels (Figure 4A,C). Expression of eNOS was not altered by aminoguanidine treatment.

The nNOS-immunoreactive bands, with a molecular weight of approximately $155 \mathrm{kDa}$, showed a significant increase in optical density in the $\mathrm{SI}+\mathrm{S}$ group at 24 and $72 \mathrm{~h}(P<0.05)$ in comparison with the $\mathrm{C}$ group levels (Figure 4A,D). At $72 \mathrm{~h}$ in the SI + AG group, the nNOS protein expression level remained elevated (Figure 4A,D).

\section{Double immunofluorescence labeling Expression of VEGF and GFAP}

Expression of VEGF was observed in widely distributed branched cells identified as GFAP-expressing astrocytes in the external plexiform layer, mitral cell layer, and internal plexiform layer (Figure 5). In the $C$ group (Figure 5A,B), GFAP and VEGF colocalization was identifiable at moderate levels (Figure $5 \mathrm{C}$ ). In the $\mathrm{SI}+\mathrm{S}$ group at 24 and $72 \mathrm{~h}$, both GFAP and VEGF immunoreactivity was markedly enhanced (Figure 5D-I), being most conspicuous at $24 \mathrm{~h}$. The vascular profiles appeared dilated with associated GFAP + VEGF-positive cell processes (Figure 5F,I), notably at $24 \mathrm{~h}$. Both GFAP and VEGF immunofluorescence was moderately attenuated at $72 \mathrm{~h}$ in the $\mathrm{SI}+\mathrm{AG}$ group (Figure 5J-L).

\section{Expression of AQP4 and GFAP}

Expression of AQP4 was ubiquitous in the astrocytic foot processes associated with the blood vessels in the external plexiform layer, mitral cell layer, and internal plexiform layer (Figure 6). Double labeling with GFAP confirmed that the AQP4-positive cells were astrocytes. In the $C$ group, both GFAP and AQP4 immunoreactivity were moderate in the olfactory bulb (Figure 6A,B); GFAP and AQP4 colocalization was only evident on closer examination (Figure $6 \mathrm{C}$ ). In the $\mathrm{SI}+\mathrm{S}$ group at 24 and $72 \mathrm{~h}$, the immunoexpression for both markers was drastically enhanced (Figure 6D-I). Strikingly, GFAP positive hypertrophic AQP4-positive astrocytic foot processes impinged on dilated blood vessels, which exhibited colocalization of GFAP immunofluorescence (Figure 6D-I). The AQP4 immunofluorescence, however, was not affected in the SI+ 


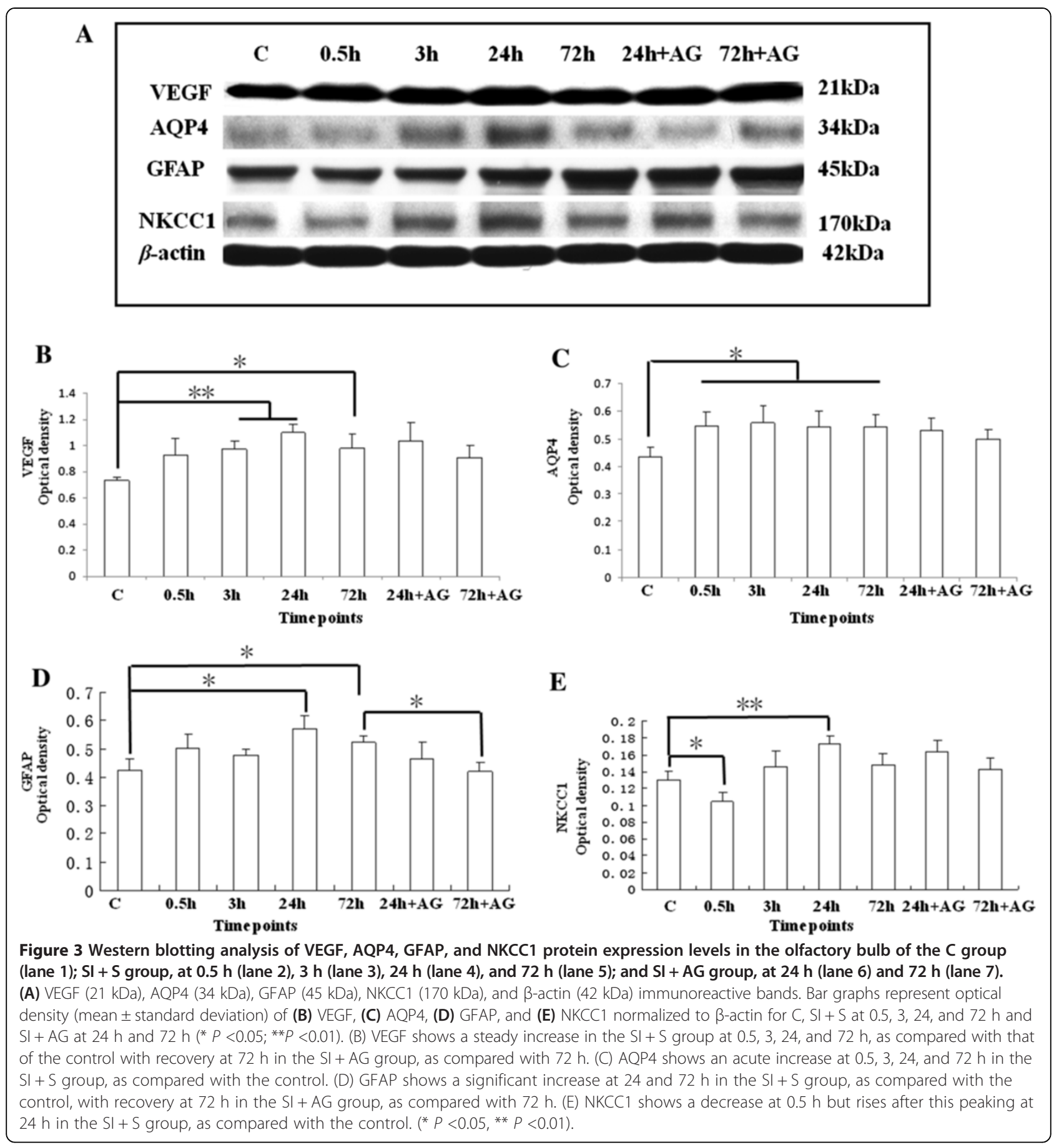

AG group at $72 \mathrm{~h}$, as compared with non-treated rats at the same time point (image not shown).

\section{Expression of nNOS and NeuN}

Expression of nNOS was observed in neurons in the external plexiform layer, mitral cell layer, internal plexiform layer, and granule cell layer (Figure 7). The nNOS-expressing cells were identified as neurons with colocalization with NeuN by double immunofluorescence labeling (Figure 7). In the $\mathrm{C}$ group (Figure 7A,B), $\mathrm{nNOS}$ and NeuN colocalization could hardly be detected (Figure $7 \mathrm{C}$ ). In the $\mathrm{SI}+\mathrm{S}$ group at 24 and $72 \mathrm{~h}$, nNOS intense immunoreactivity was detected in some NeuN-positive neurons (Figure 7D-I) with a higher incidence at $24 \mathrm{~h}$. Intense nNOS immunoreactivity was localized in the nucleus, whose outlined is well defined (Figure 7F,I,L). Aminoguanidine did not obviously suppress the immunofluorescence of $\mathrm{nNOS}$ at 72 h (Figure 7J-L). 


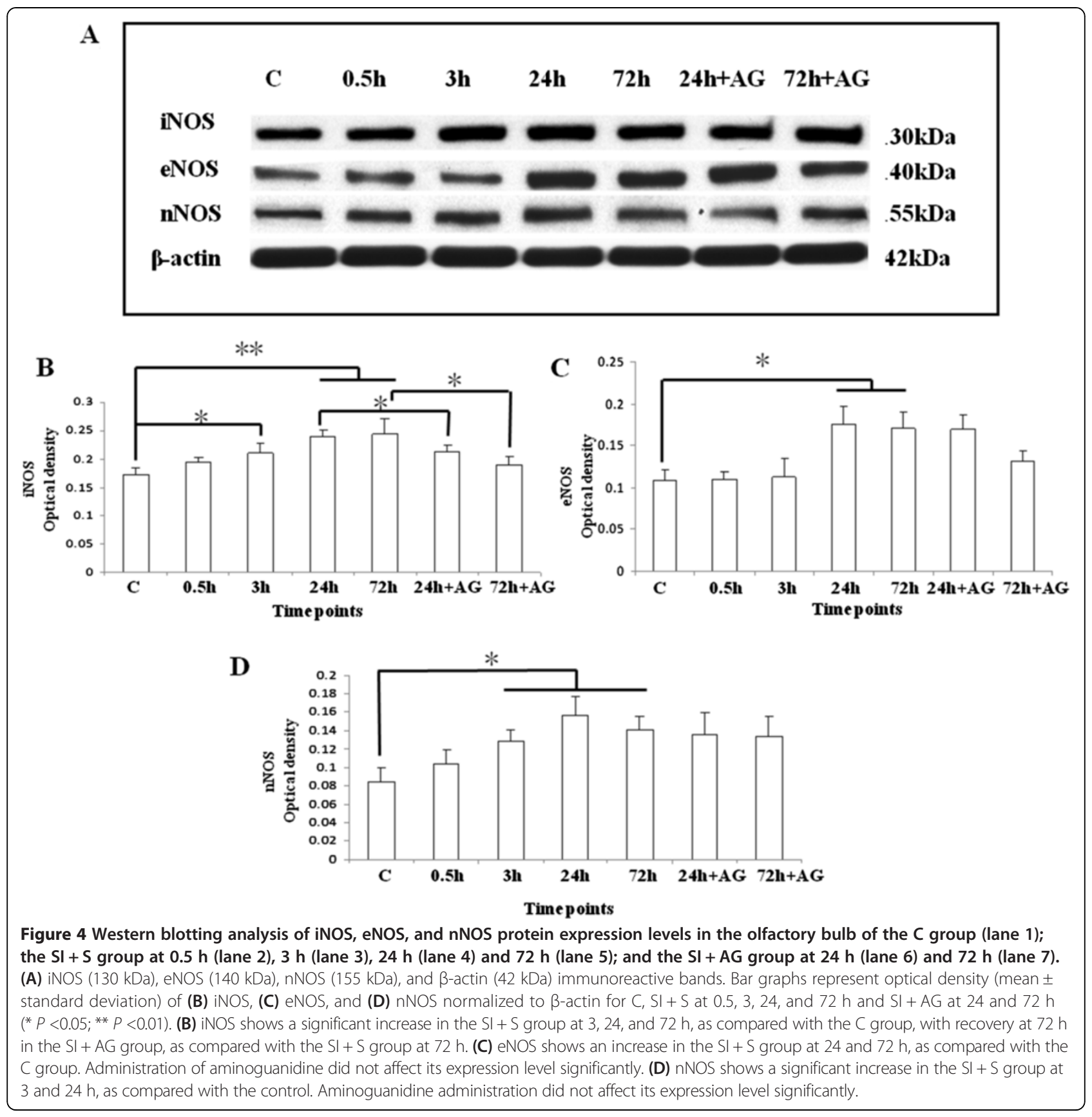

\section{Expression of NKCC1 and GFAP}

Expression of NKCC1 was observed in some GFAPexpressing cells in the external plexiform layer, mitral cell layer, and internal plexiform layer (Figure 8). In the $C$ group (Figure 8A,B), moderate NKCC1 immunofluorescence was detected in the soma of occasional astrocytes (Figure $8 \mathrm{C}$ ). In the $\mathrm{SI}+\mathrm{S}$ group at 24 and $72 \mathrm{~h}$, both GFAP and NKCC1 immunoreactivity were markedly increased (Figure 8D-I), notably at $24 \mathrm{~h}$. In the $\mathrm{SI}+\mathrm{AG}$ group at $72 \mathrm{~h}$, both GFAP and NKCC1 immunofluorescence were decreased, as compared with the $\mathrm{SI}+\mathrm{S}$ group at the same time point (Figure 8J-L).

\section{Expression of NKCC1 and NeuN}

Expression of NKCC1 was localized in some astrocytes, but some NKCC1-expressing cells were identified as the neurons labeled by NeuN (Figure 9A-F). In the $\mathrm{C}$ group (Figure 9A,B), NKCC1 immunofluorescence was detected in sporadic neurons (Figure $9 \mathrm{C}$ ). In the $\mathrm{SI}+\mathrm{S}$ 


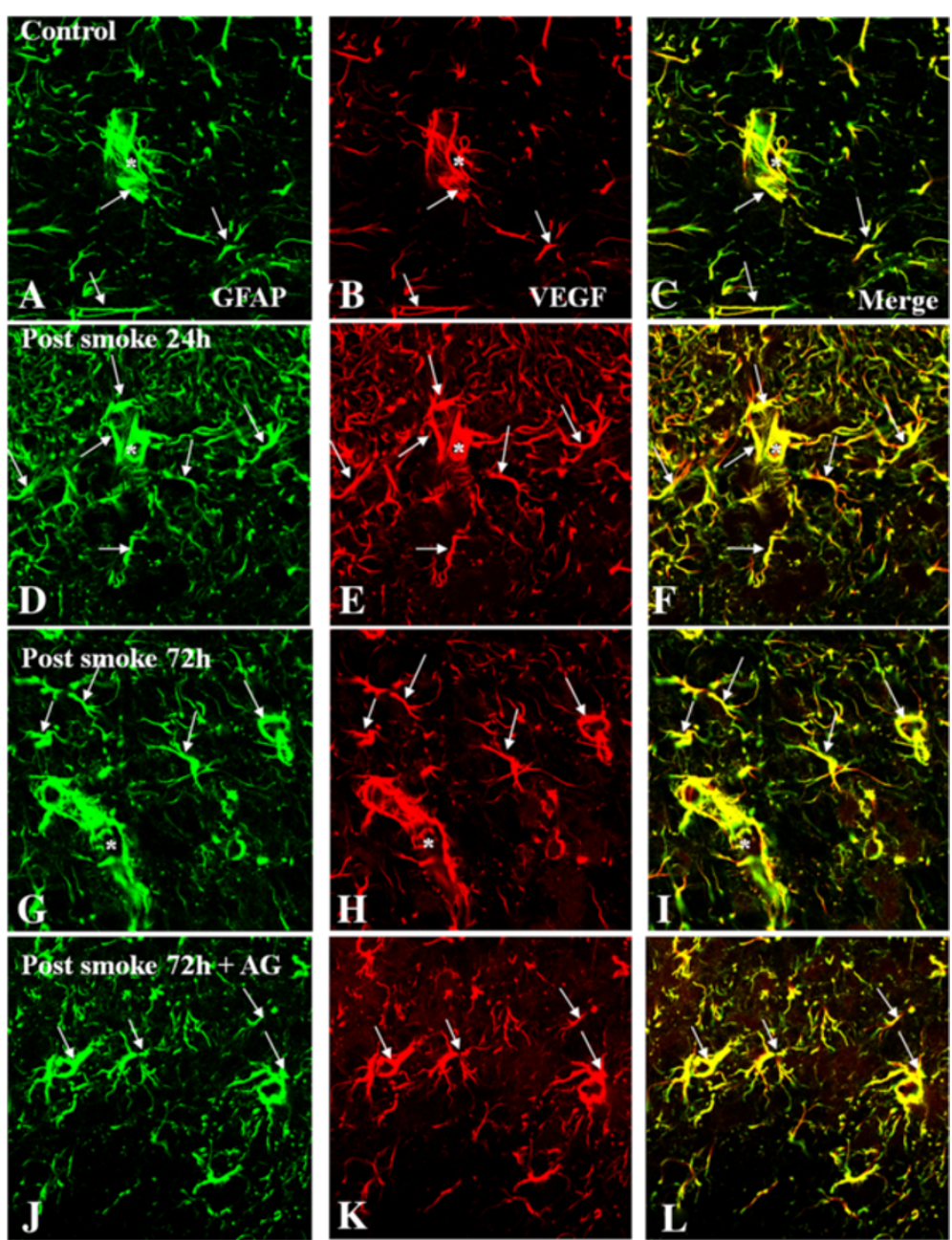

Figure 5 VEGF (red) and GFAP (green) immunopositive astrocytes in the external plexiform layer, mitral cell layer, and internal plexiform layer in the olfactory bulb of the $\mathrm{C}$ group (A-C), SI + S group at 24 and $72 \mathrm{~h}(\mathrm{D}-\mathrm{I})$, and $\mathrm{SI}+\mathrm{AG}$ group at $72 \mathrm{~h}(\mathrm{~J}-\mathrm{L})$. In the control, moderate VEGF immunofluorescence is detected in GFAP-labeled astrocytes. In the SI + S group, VEGF immunofluorescence is evidently enhanced in hypertrophic astrocytes at 24 and 72 h (D-I), notably at $24 \mathrm{~h}$ (E). Colocalized expression of VEGF with GFAP immunoreactive astrocytes (arrows) and the lumen of blood vessels (asterisks) can be seen in $\mathbf{C}, \mathbf{F} \mathbf{I}$, and $\mathbf{L}$. Immunoreactivity for both VEGF and GFAP is attenuated in the $\mathrm{SI}+\mathrm{AG}$ group at $72 \mathrm{~h}$, as compared with the $\mathrm{SI}+\mathrm{S}$ group at corresponding time point (J-L). Scale bar $=20.0 \mu \mathrm{m}$.

group at $24 \mathrm{~h}$, the incidence of NKCC1-expressing neurons was increased (Figure 9D-F).

Aminoguanidine decreased nitric oxide levels in the olfactory bulb after smoke inhalation

The NO levels in the olfactory bulb tissues, as determined by nitrite level, were significantly increased $(P<0.01)$ in the $\mathrm{SI}+\mathrm{S}$ group at $0.5,3,24$, and $72 \mathrm{~h}$, as compared with the $C$ group (Figure $9 \mathrm{G}$ ). Aminoguanidine administration ( $\mathrm{SI}+\mathrm{AG}$ ) significantly suppressed NO production at 24 and $72 \mathrm{~h}(P<0.05)$, as compared with the SI $+\mathrm{S}$ group (Figure $9 \mathrm{G}$ ). In the SI $+\mathrm{L}-\mathrm{NAME}$ group, NO levels remained relatively unchanged at 3, 24 , and $72 \mathrm{~h}$, as compared with the $\mathrm{SI}+\mathrm{S}$ group (Figure 9G).
Elevated glutamate in olfactory bulb after smoke inhalation

Glutamate levels in the samples of olfactory bulb were significantly increased in the SI $+\mathrm{S}$ group at 3,24 , and $72 \mathrm{~h}$ $(P<0.01)$, peaking at $24 \mathrm{~h}$ in comparison with the control levels (Figure 9H). Upon aminoguanidine administration $(\mathrm{SI}+\mathrm{AG})$, glutamate levels appeared to decrease at 24 and $72 \mathrm{~h}$, compared with the SI $+\mathrm{S}$ group, but this was not significant (Figure 9H).

\section{RITC extravasation in olfactory bulb after smoke} inhalation

In the control group, RITC extravasation was not evident in the different layers of the olfactory bulb (Figure 10B). RITC was barely detected in GFAP-labeled astrocytes in the $\mathrm{C}$ group (Figure $10 \mathrm{~A}-\mathrm{C}$ ). In the $\mathrm{SI}+\mathrm{S}$ group, the 

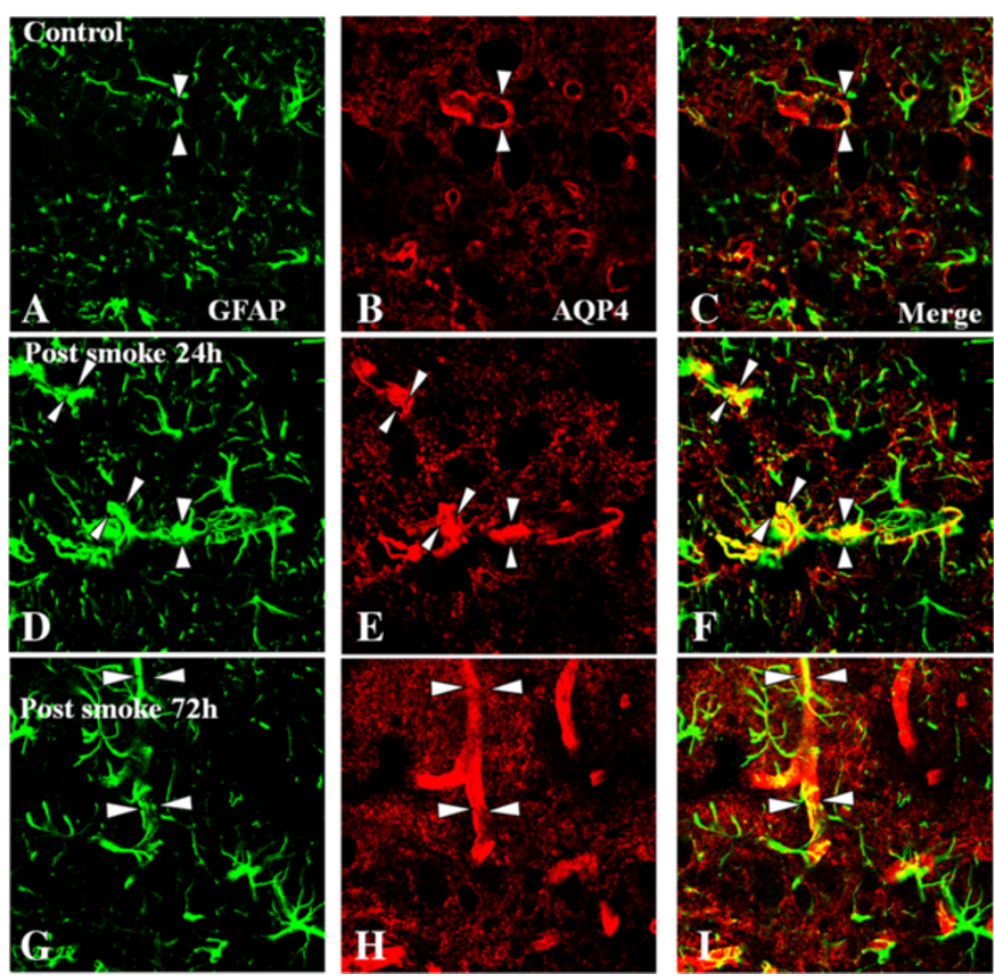

Figure 6 Immunoexpression of AQP4 (red) and GFAP (green) in the olfactory bulb of the C group (A-C) and the SI + S group at 24 and $72 \mathrm{~h}$ (D-I). In the normal olfactory tissue, AQP4 expression is localized in the astrocytic foot processes (arrows) and blood vessels (arrowheads) (A-C). In the $\mathrm{SI}+\mathrm{S}$ group, AQP4 expression is increased at different time points (24 and $72 \mathrm{~h}, \mathbf{D}-\mathbf{I}$ ), being more conspicuous at $24 \mathrm{~h}$ (E). Intense AQP4 immunoreactivity is localized in GFAP-labeled astrocyte processes and end-feet and blood vessels, which are well delineated (C,F,I).

Aminoguanidine administration did not suppress the immunofluorescence at $72 \mathrm{~h}$ (image not shown). Scale bar $=20.0 \mu \mathrm{m}$.

olfactory bulb tissue was inundated with RITC dye, which permeated the entire neuropil (Figure 10E). In some areas, extravasated RITC overlapped with the blood vessels, as revealed by GFAP immunofluorescence labeling (Figure 10F,I). The extravasated RITC appeared to be internalized by the astrocytes, as demonstrated by its colocalization with GFAP. In the SI + AG group, RITC leakage was only moderately reduced (Figure $10 \mathrm{H}$ ).

\section{Smoke inhalation increased apoptosis in olfactory bulb}

Smoke inhalation-induced apoptosis was observed in the external plexiform layer, mitral cell layer, internal plexiform layer, and granule cell layer (Figure 11). The number of cells undergoing apoptosis as evidenced by TUNEL labeling was markedly increased $(P<0.01)$ in the $\mathrm{SI}+\mathrm{S}$ group at $72 \mathrm{~h}$, as compared with the $\mathrm{C}$ group (Figure 11A-D). In the SI + AG group, the number of TUNEL-positive cells was reduced compared with those without drug treatment at $72 \mathrm{~h}$, but the decrease was not statistically significant (Figure 11B-D).

\section{Discussion}

The effect of combustion smoke inhalation on the central nervous system has been reported, but there is a lack of information on its effects on the olfactory bulb. Injury to the central nervous system has been attributed to several factors, such as acute or chronic respiratory distress [22], ischemia, and carbon monoxide intoxication [23,24]. We previously demonstrated that a hypoxic high carbon monoxide environment resulted in drastic systemic and central nervous system changes in an experimental rodent model of combustion smoke inhalation $[12,13]$. This study aims to determine the effect of smoke inhalation on the olfactory bulb. The present findings suggest that the upregulation of iNOS in response to smoke inhalation plays a major role in olfactory bulb inflammatory pathophysiology after smoke inhalation, with concomitant increases in pro-inflammatory molecules, vascular permeability, and edema.

The pathologic or pathophysiologic changes induced by carbon monoxide or hypoxic exposure to the olfactory bulb remains unclear. A study investigating the effects of smoke on the central nervous system reported that nicotine was the principal pharmacological constituent of tobacco smoke [25]. A hypoxic stimulus to the brain has been associated with the production of large amounts of inflammatory mediators, such as TNF- $\alpha$ and IL-1 $\beta[26,27]$. In this study, expression levels of TNF- $\alpha$, 

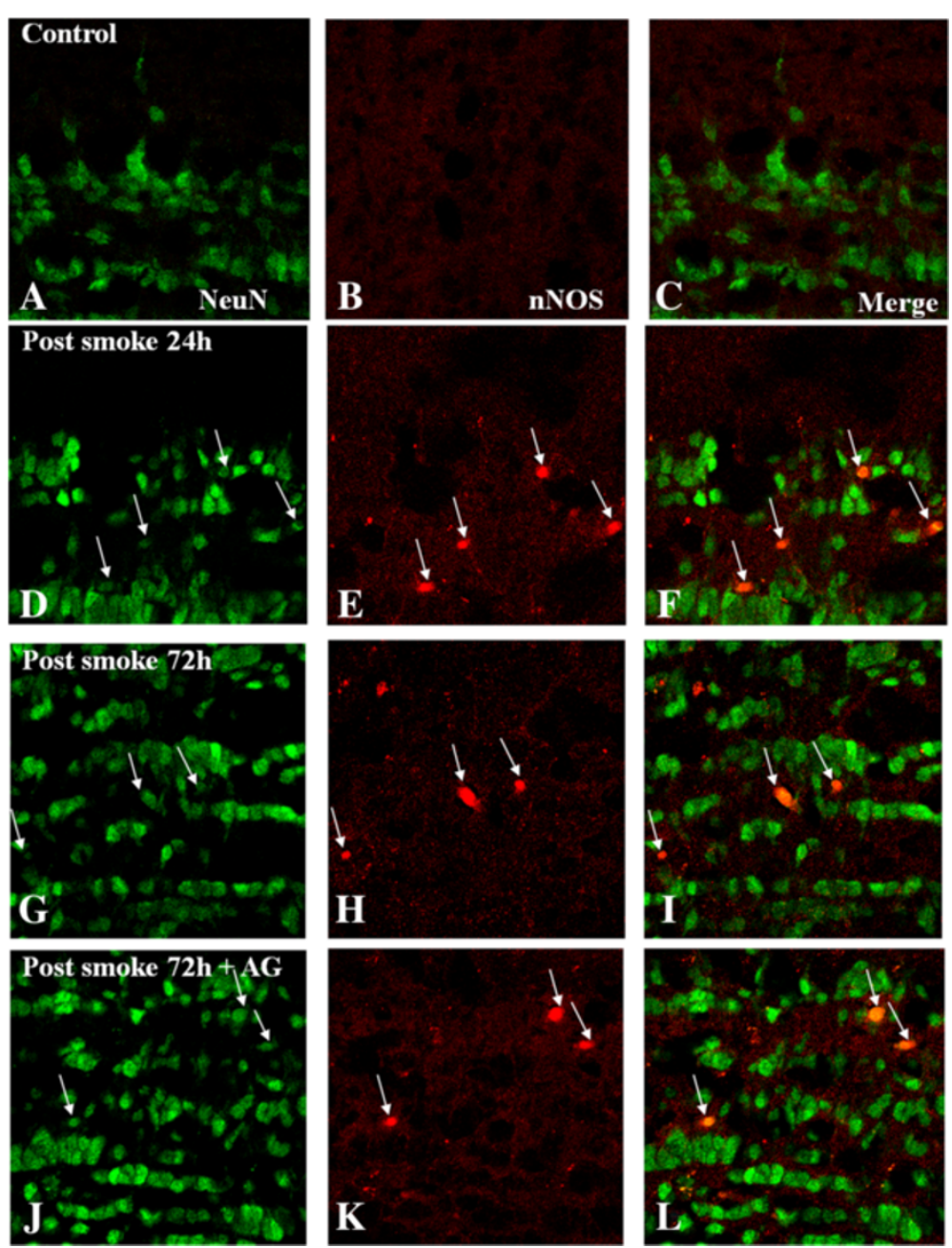

Figure 7 Immunoexpression of nNOS (red) and NeuN (green) in the olfactory bulb of the C group (A-C), the SI + S group at 24 and 72 $\mathbf{h}(\mathbf{D}-\mathbf{I})$, and the SI + AG group at $\mathbf{7 2} \mathbf{~ h}(\mathbf{J}-\mathbf{L})$. In the normal bulb, nNOS expression is absent (A-C); however, in the $\mathrm{SI}+\mathrm{S}$ group, it is induced in some neurons at different time points ( 24 and $72 \mathrm{~h}, \mathbf{D}-\mathbf{l}$ ); the incidence of labeled cells is higher at $24 \mathrm{~h}$ (E). Aminoguanidine administration did not obviously alter the immunofluorescence at $72 \mathrm{~h} \mathrm{(J-L)}$. Scale bar $=20.0 \mu \mathrm{m}$.

IL-1 $\beta$, and IL-12 were immediately increased in the olfactory bulb at $24 \mathrm{~h}$ after smoke inhalation. This suggests the initiation of an acute inflammatory response in the olfactory bulb in response to smoke. There are a number of possible mediators in this reactive response to the smoke inhalation insult.

It has been reported that VEGF plays a role in the inflammatory process by inducing the expression of iNOS and eNOS [28]. Moreover, VEGF can induce NO production and eNOS phosphorylation [29]. VEGF may play a modulating role in the central nervous system by mediating the permeability of the blood-brain barrier. In doing so, the brain may now become more immunocompromised, as it is exposed to blood-borne immune mediators that are normally sequestered away from the brain [30]. In this study, an immediate increase in protein expression of VEGF, iNOS, eNOS, and nNOS was observed at 3 and 24 $\mathrm{h}$ after combustion smoke inhalation in the olfactory bulb. The enhanced expression of iNOS was decreased by aminoguanidine administration at 24 and $72 \mathrm{~h}$. In addition, VEGF plays a role in mediating vasodilation and, consequently, the movement of water molecules and large molecular weight proteins from blood vessels into the tissue, resulting in edema [31]. VEGF is overexpressed in reactive astrocytes under pathologic conditions, and has been associated with the breakdown of the blood-brain barrier [30]. The suppression of NO production in endothelial cells has been reported to inhibit endothelial permeability due to VEGF [32]. In this study, we showed that VEGF and NO levels were both increased in the olfactory bulb at 24 and $72 \mathrm{~h}$ after smoke inhalation. In particular, VEGF and NO levels were mainly enhanced in the blood vessels and astrocytes. The increase in VEGF expression was associated with an increased in the permeability of the blood 

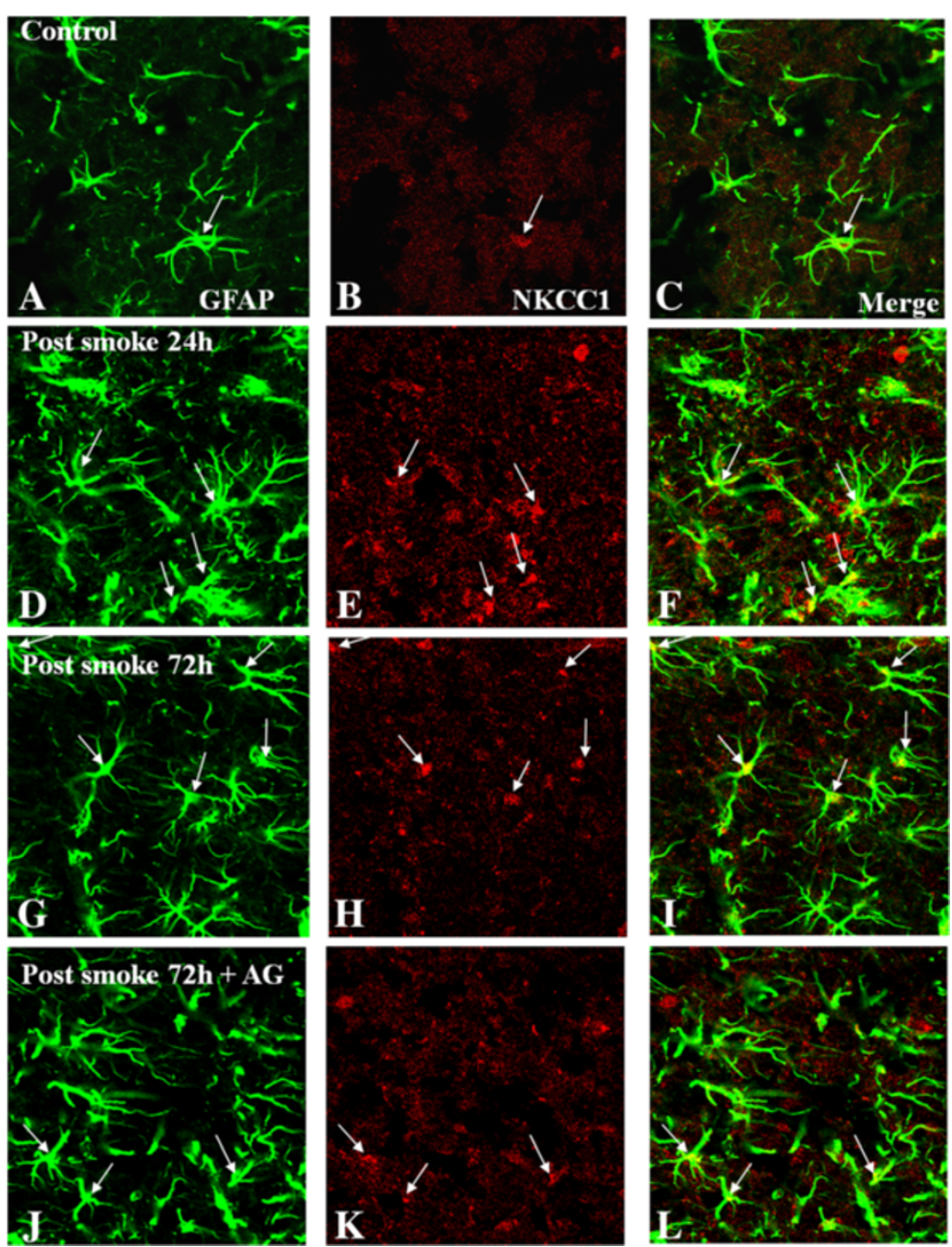

Figure 8 NKCC1 (red) and GFAP (green) immunopositive astrocytes in the bulb tissue of the control group (A-C), the SI + S group at 24 and $72 \mathrm{~h}(\mathrm{D}-\mathrm{I})$, and the SI + AG group at $72 \mathrm{~h}(\mathrm{~J}-\mathrm{L})$. In the C group, only sporadic astrocytes exhibit moderate NKCC1 immunofluorescence. In the $\mathrm{SI}+\mathrm{S}$ group, it is evidently enhanced in hypertrophic astrocytes at 24 and $72 \mathrm{~h}$ (D-I), being more pronounced at $24 \mathrm{~h}$ (E). Colocalized expression of NKCC1 with GFAP immunoreactive astrocytes (arrows) can be seen in $\mathbf{C}, \mathbf{F}$, I and $\mathbf{L}$. Immunoreactivity for both NKCC1 and GFAP is attenuated at $72 \mathrm{~h}$ in the $\mathrm{SI}+\mathrm{AG}$ group, as compared with the $\mathrm{SI}+\mathrm{S}$ group at $72 \mathrm{~h}$ (J-L). Scale bar $=20.0 \mu \mathrm{m}$.

vessels in the olfactory bulb, as demonstrated by a leakage of RITC from the periphery into the olfactory bulb tissue at $24 \mathrm{~h}$ after smoke inhalation. This suggests that VEGF may mediate vascular permeability. Aminoguanidine treatment drastically decreased the expression levels of VEGF, GFAP, and NO at 24 and $72 \mathrm{~h}$ after smoke inhalation, as confirmed by both immunofluorescence and Western blot analysis. Aminoguanidine also decreased RITC intensity in the olfactory bulb, albeit moderately, at $24 \mathrm{~h}$ after smoke inhalation, suggesting that aminoguanidine administration can decrease vascular permeability, VEGF expression, and GFAP + astrocyte hypertrophy after smoke inhalation.

Nitric oxide is a small gaseous molecule. Physiologically, nitric oxide plays roles in vasodilation and hence vascular permeability [33,34], neurotransmission and antiplatelet aggregation. Pathologically, nitric oxide may serve to trigger inflammatory pathways, owing to increased upregulation from either neuronal, endothelial or inducible NOS, and may also function as a free radical, contributing to oxidative damage. As in our previous studies, a significant increase in NO production was observed in the olfactory bulb after smoke inhalation in addition to the other parts of the central nervous system investigated $[12,13]$.

To determine the source of NO production in response to smoke inhalation, the selective iNOS inhibitor (aminoguanidine) or nNOS/eNOS constitutive inhibitor (L-NAME) [35] was administered separately. Nitric oxide levels were significantly suppressed with aminoguanidine administration but not with L-NAME administration. This suggests that iNOS is responsible for $\mathrm{NO}$ production in response to the smoke challenge 

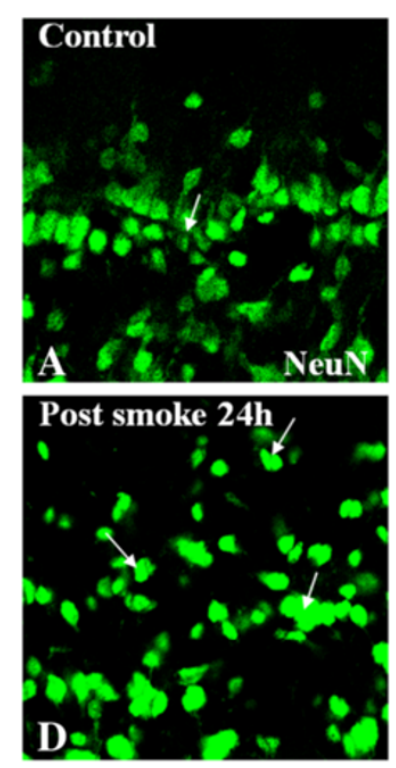

\section{G NO Concentration $(\mu \mathrm{M})$}

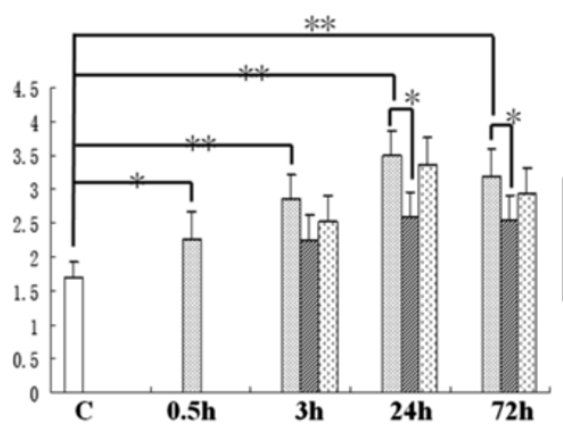

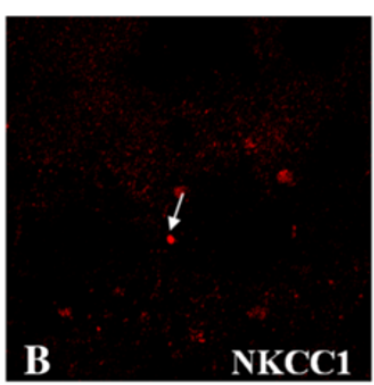
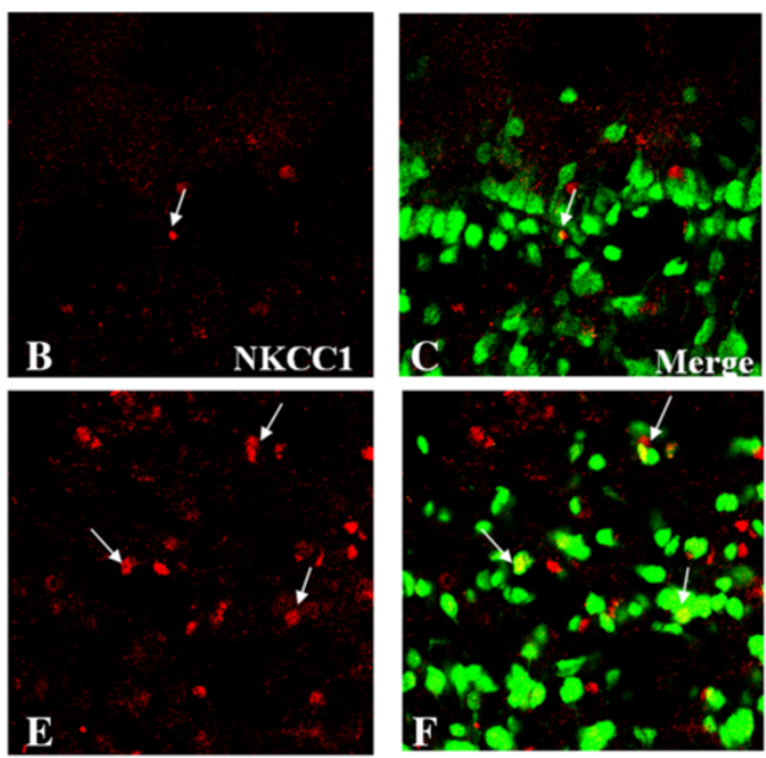

H Glutamate content $(\mathrm{mg} / \mathrm{ml})$
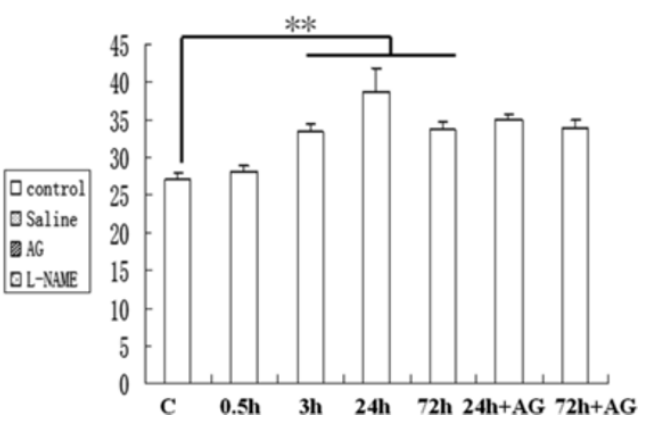

Figure 9 Immunoexpression of NKCC1 (red) and NeuN (green) in different layers of the olfactory bulb (A-F). Scale bar =20 $\mu \mathrm{m}$ (A-F). NO content $(\mu \mathrm{M})$ and glutamate concentration $(\mathrm{mg} / \mathrm{ml})$ analysis $(\mathbf{G}, \mathbf{H})$ in the olfactory bulb of the $\mathrm{C}$ group, the $\mathrm{SI}+\mathrm{S}$ group $(0.5,3,24$, and $72 \mathrm{~h})$ and the $\mathrm{SI}+\mathrm{AG}$ or SI + L-NAME groups $\left(3,24\right.$, and $72 \mathrm{~h}$ ) compared with the C group. ( ${ }^{*} P<0.05$; $\left.{ }^{* *} P<0.01\right)$. (A-F) Colocalized expression of NKCC1 with NeuN immunoreactive neurons (arrows) is detected in the $C$ group. Note that a large number of NeuN-positive neurons are double labeled with NKCC1 (F) compared with the C group (C). (G) $[\mathrm{NO}] / \mu \mathrm{M}$ is significantly increased in the olfactory bulb in $\mathrm{SI}+\mathrm{S}$ group at $0.5,3,24$, and $72 \mathrm{~h}$, as compared with the C group; however, [NO] is significantly suppressed in $\mathrm{SI}+\mathrm{AG}$ group at 24 and $72 \mathrm{~h}$, as compared with saline administration: $[\mathrm{NO}]$ is not significantly suppressed at 24 and $72 \mathrm{~h}$ in the $\mathrm{SI}+\mathrm{L}-\mathrm{NAME}$ group, as compared with the $\mathrm{SI}+\mathrm{S}$ group. (H) Glutamate concentration is significantly increased in the olfactory bulb in the $\mathrm{SI}+\mathrm{S}$ group at 3, 24, and $72 \mathrm{~h}$, as compared with that of the C group; it is not significantly suppressed in the $\mathrm{SI}+\mathrm{AG}$ group at 24 and $72 \mathrm{~h}$, as compared with the $\mathrm{SI}+\mathrm{S}$ group.

and that NO production may mediate the permeability of blood vessels.

AQP4 is a membrane protein that allows for the passage of water through the cell membrane. In particular, AQP4 is found in high concentrations in the perivascular membranes of astrocytes in various mammalian brains [36-38]. AQP4 is also expressed in astrocytic endfeet surrounding endothelial cells lining blood vessels [39]. AQP4 has been implicated in the formation of brain edema due to various injurious insults [36-38]. We have previously reported AQP4 upregulation in the retina and cerebellum of adult rats subjected to smoke inhalation, suggesting its involvement in edema formation of the retina and brain [12,13]. In this study, AQP4 expression was markedly increased in the olfactory bulb after smoke inhalation, especially in the astrocytic foot processes. This further supports the intimate relationship between blood-brain barrier function and the control of water flow by astrocytes. Furthermore, AQP4 has been reported to be strongly expressed in the glomerulus of the olfactory bulb and might play a role in olfactory function [40]. The disruption of olfaction may predispose the individual to neurodegenerative diseases and may also contribute to olfactory problems in dangerous environments, such as in a fire. It is unclear whether the sense of smell is affected by smoke. The animals were observed to have labored breathing immediately after smoke inhalation with recovery to basal rates by $24 \mathrm{~h}$ 

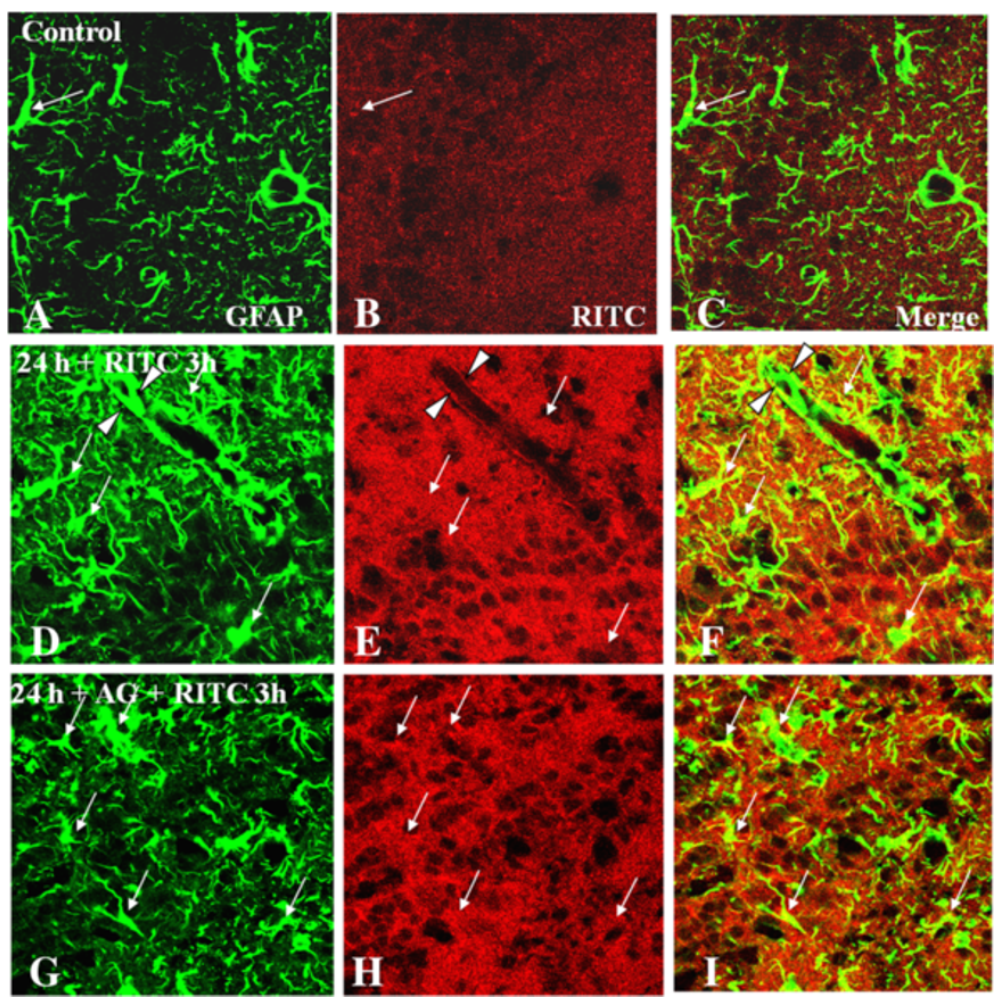

Figure 10 Extravasation of RITC (red) in the olfactory bulb of the $\mathrm{C}$ group (A-C), the $\mathrm{SI}+\mathrm{S}$ group at $24 \mathrm{~h}$ (D-F), and the $\mathrm{SI}+\mathrm{AG}$ group at $\mathbf{2 4} \mathbf{h}(\mathbf{G}-\mathbf{I})$. In the $\mathrm{C}$ group, the olfactory bulb tissue emits very weak RITC fluorescence (B,C), which is also detected in GFAP-labeled astrocytes (arrow) in B. In the SI + S group and at $3 \mathrm{~h}$ after RITC administration, RITC fluorescence (asterisks) appears to permeate the neuropil (D-F). In some areas, extravasated RITC superimposes with the blood vessels (arrowhead) (F,I). In the SI + AG group, RITC leakage is moderately reduced, as shown by the attenuated fluorescence (G-I). Scale bar $=20.0 \mu \mathrm{m})$.

after smoke inhalation. No other behavioral changes were observed. Long-term effects on smell and behavior was also not observed, as animals were sacrificed by $2 \mathrm{w}$ after smoke inhalation.

In this study, RITC was shown to permeate the neuropil in rats subjected to smoke inhalation; furthermore, the tracer extravasation appeared to be acute, as it was evident as early $3 \mathrm{~h}$ after its administration. The same phenomenon was also observed in the cerebellum and hippocampus after smoke inhalation. These results suggest that vascular permeability in the olfactory bulb is vulnerable to smoke inhalation and that the integrity of the blood-brain barrier was compromised. One contributing factor to this would be the upregulated AQP4 expression in the olfactory bulb after smoke inhalation.

NKCC1 activates the mitogen-activated protein kinase (MAPK) cascade, which serves to induce edema and brain injury in response to TBI [18]. In a separate study, NKCC1 has also been shown to mediate inflammatory responses where inhibition of NKCC1 prevents the progression of inflammation [41]. In this study, we also found increased NKCC1 protein expression, along with various cytokines and chemokines at 24 and $72 \mathrm{~h}$ after smoke inhalation. Immunoexpression of NKCC1 was specifically localized in GFAP + hypertrophic astrocytes as well as $\mathrm{NeuN}+$ neurons at 24 and $72 \mathrm{~h}$ after smoke inhalation. It has been reported that oxygen-glucose deprivation induced approximately $67 \%$ cell death and a four-fold increase in NKCC1+ cortical neurons. The inhibition of NKCC1 resulted in a protection of NKCC1 expressing neurons and astrocytes. These suggest that enhanced NKCC1 activity is linked to ischemic neuronal damage [42]. In our study, a significant increase in apoptosis appeared to coincide with increased NKCC1 protein expression at $72 \mathrm{~h}$ after smoke inhalation, thus supporting the notion that both are interrelated.

In another study, exposure to nanoparticle-rich diesel exhaust resulted in glutamate-induced neurotoxicity accompanied by changes in the expression of $\mathrm{N}$-methylD-aspartate receptor subunits and related kinase and transcription factor in the mouse olfactory bulb [43]. The present results show that the glutamate levels in olfactory bulb tissue increased at 24 and $72 \mathrm{~h}$ after smoke inhalation, suggesting that glutamate homeostasis is disrupted after smoke inhalation and might play a role in altering olfactory function. It is possible that glutamateinduced toxicity might contribute to cell death in the olfactory bulb after smoke inhalation. 

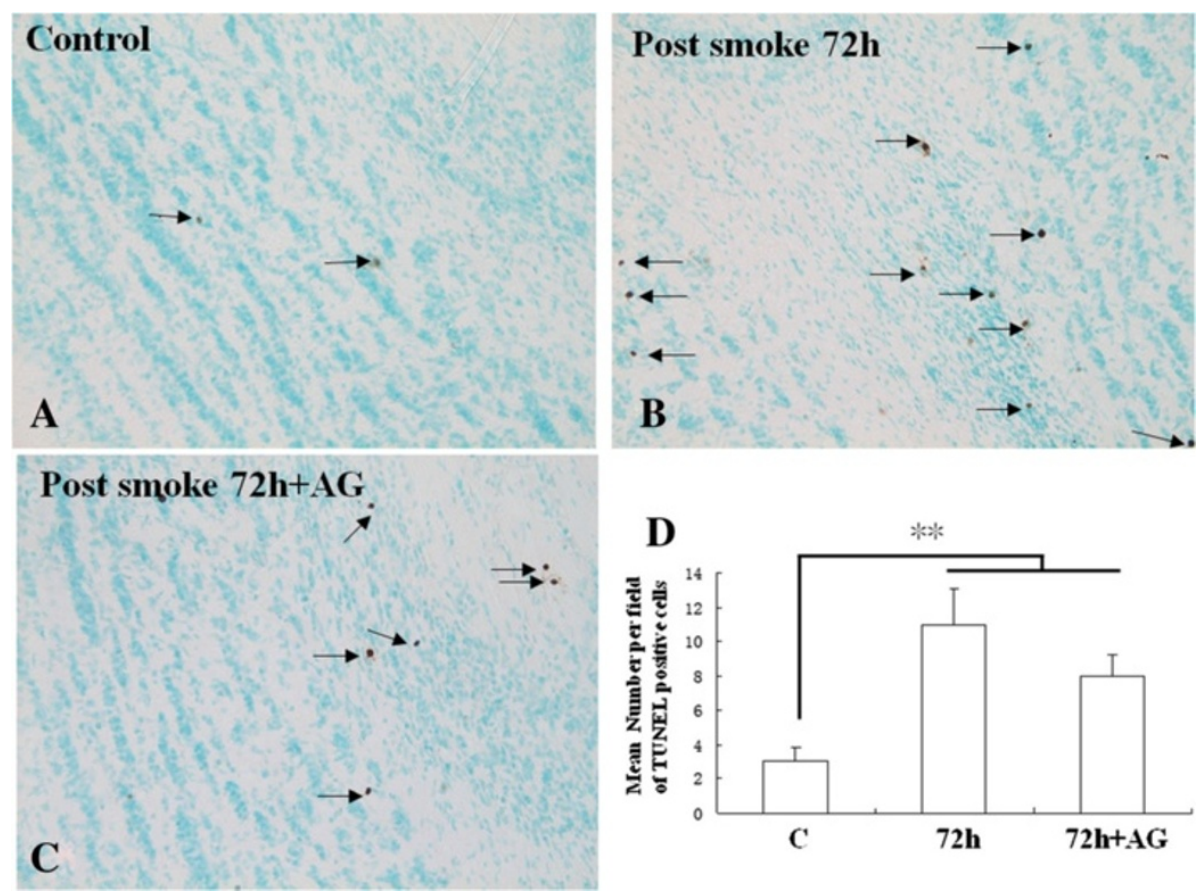

Figure 11 TUNEL immunopositive cells in the external plexiform layer, mitral cell layer, internal plexiform layer, and granule cell layer in the $\mathrm{C}$ group (A), the $\mathrm{SI}+\mathrm{S}$ group at $72 \mathrm{~h}(\mathrm{~B})$, and the $\mathrm{SI}+\mathrm{AG}$ group at $72 \mathrm{~h}$ (C). Smoke inhalation increases the incidence of apoptotic cells (arrows) in the mitral cell layer (B) compared with the C group (A). The frequency of apoptotic cells in the olfactory bulb is significantly reduced in the $\mathrm{SI}+\mathrm{AG}$ group at $72 \mathrm{~h}$, as compared with the $\mathrm{SI}+\mathrm{S}$ group (C). Scale bar $=50 \mu \mathrm{m}$. (D) Bar graphs show increase in apoptotic cells in the $\mathrm{SI}+\mathrm{S}$ group at $72 \mathrm{~h}$, as compared with the $\mathrm{C}$ group. Apoptotic cells are significantly suppressed in numbers in the $\mathrm{SI}+\mathrm{AG}$ group at $72 \mathrm{~h}$, as compared with $\mathrm{SI}+\mathrm{S}$.

\section{Conclusions}

Combustion smoke inhalation upregulates the expression or production of VEGF, GFAP, AQP4, NKCC1, iNOS, eNOS, nNOS, NO, and glutamate in the adult rat olfactory bulb. This was coupled by a rise in inflammatory mediators and an increase in apoptosis, increased blood permeability, and tissue edema. It is suggested that these changes might collectively contribute to olfactory bulb injury after smoke inhalation. It is postulated that hypoxia and high levels of carbon monoxide $m$ cause the changes in the olfactory bulb. Administration of aminoguanidine, an iNOS inhibitor, was found to reduce the production of $\mathrm{NO}$ and the extravasation of RITC dye into the olfactory bulb, implicating iNOS as a major contributor in the pathophysiology of olfactory bulb injury after smoke inhalation.

\footnotetext{
Abbreviations

ANOVA: analysis of variance; AQP4: aquaporin-4; BSA: bovine serum albumin; C: control; DAPI: 4',6-diamidino-2-phenylindole; ELISA: enzyme-linked immunosorbent assay; eNOS: endothelial nitric oxide synthase; GFAP: glial fibrillary acidic protein; $H$ \& E: hematoxylin and eosin; IL-1 $\beta$ : interleukin-1 $\beta$; iNOS: inducible nitric oxide synthase; L-NAME: L-NG-nitroarginine methyl ester; MAPK: mitogen-activated protein kinase; NKCC1: $\mathrm{Na}^{+}-\mathrm{K}^{+}-\mathrm{Cl}^{-}$ cotransporter 1; NOS: nitric oxide synthase; nNOS: neuronal nitric oxide synthase; PBS: phosphate buffered saline; RITC: rhodamine isothiocyanate; SI + AG: smoke inhalation plus aminoguanidine; SI + L-NAME: smoke inhalation plus NG nitro $L$ arginine methyl ester; $\mathrm{SI}+\mathrm{S}$ : smoke inhalation plus
}

saline; TBS: Tris-buffered saline; TNF-a: tumor necrosis factor-a; TUNEL: terminal deoxynucleotidyl transferase dUTP nick end labeling; VEGF: vascular endothelial growth factor.

\section{Competing interests}

The authors declare that they have no competing interests.

\section{Authors' contributions}

$\mathrm{E}-\mathrm{AL}$ and $J \mathrm{~L}$ designed the experimental project. $\mathrm{Y}-\mathrm{YZ}$, EMK, and $\mathrm{YY}$ carried out the experiments and prepared the manuscript. All authors participated in discussion, analysis of data, and editing, and approved the final manuscript.

\section{Acknowledgements}

This project is supported by the National University of Singapore project number R-180-000-140-592 (E-AL).

\section{Author details}

${ }^{1}$ Department of Pathology and Pathophysiology, Faculty of Basic Medical Sciences, Kunming Medical University, 1168 West Chunrong Road, Kunming 650500, PR China. ${ }^{2}$ Department of Anatomy and Histology/Embryology, Faculty of Basic Medical Sciences, Kunming Medical University, 1168 West Chunrong Road, Kunming 650500, PR China. ${ }^{3}$ Defense Medical and Environmental Research Institute, DSO National Laboratories, 27 Medical Drive, Singapore 117510, Singapore. ${ }^{4}$ Department of Anatomy, Yong Loo Lin School of Medicine, National University of Singapore, 4 Medical Drive, MD10, Singapore 117597, Singapore.

Received: 12 August 2014 Accepted: 29 September 2014

Published online: 10 October 2014

\section{References}

1. Song C, Leonard BE: The olfactory bulbectomised rat as a model of depression. Neurosci Biobehav Rev 2005, 29:627-647. 
2. Whitman $M C$, Greer CA: Adult neurogenesis and the olfactory system. Prog Neurobiol 2009, 89:162-175.

3. Tsuno $Y$, Kashiwadani $\mathrm{H}$, Mori K: Behavioral state regulation of dendrodendritic synaptic inhibition in the olfactory bulb. J Neursci 2008, 28:9227-9238.

4. Nugent $N$, Herndon DN: Diagnosis and treatment of inhalation injury. In Total Burn Care. 3rd edition. Edited by Herndon DN. Philadelphia, PA: WB Saunders; 2007:262-272.

5. Leopoldo CC, Basil AP Jr: Inhalation injury. In Combat Medicine: Basic and Clinical Research in Military, Trauma, and Emergency. Medicine. Edited by Tsokos GC, Atkins JL. New York, NY: Humana Press, Inc; 2003:325-350.

6. Whitehead GS, Grasman KA, Kimmel EC: Lung function and airway inflammation in rats following exposure to combustion products of carbon-graphite/epoxy composite material: comparison to a rodent model of acute lung injury. Toxicology 2003, 83:175-197.

7. Toon MH, Maybauer MO, Greenwood JE, Maybauer DM, Fraser JF: Management of acute smoke inhalation injury. Crit Care Resusc 2010, 12:53-61.

8. Shirani KZ, McManus AT, Vaughan GM, McManus WF, Pruitt BA Jr, Mason $A D \mathrm{Jr}$ : Effects of environment on infection in burn patients. Arch Surg 1986, 121:31-36

9. Lee HM, Greeley GH, Herndon DN, Sinha M, Luxon BA, Englander EW: A rat model of smoke inhalation injury: influence of combustion smoke on gene expression in the brain. Toxicol Appl Pharmacol 2005, 208:255-265.

10. Lee HM, Reed J, Greeley GH Jr, Englander EW: Impaired mitochondrial respiration and protein nitration in the rat hippocampus after acute inhalation of combustion smoke. Toxicol Appl Pharmacol 2009, 235:208-215.

11. Lee HM, Greeley GH Jr, Englander EW: Transgenic overexpression of neuroglobin attenuates formation of smoke-inhalation-induced oxidative DNA damage, in vivo, in the mouse brain. Free Radic Biol Med 2011, 51:2281-2287.

12. Zou YY, Lu J, Poon DJ, Kaur C, Cao Q, Teo AL, Ling EA: Combustion smoke exposure induces up-regulated expression of vascular endothelial growth factor, aquaporin 4, nitric oxide synthases and vascular permeability in the retina of adult rats. Neuroscience 2009, 160:698-709.

13. Zou YY, Kan EM, Cao Q, Lu J, Ling EA: Combustion smoke-induced inflammation in the cerebellum and hippocampus of adult rats. Neuropathol Appl Neurobiol 2013, 39:531-552.

14. Binienda Z, Holson RR, Chen FX, Oriaku E, Kim CS, Flynn TJ, Slikker W Jr, Paule MG, Feuers R, Ferguson SA: Effects of ischemia-hypoxia induced by interruption of uterine blood flow on fetal rat liver and brain enzyme activities and offspring behavior. Int J Dev Neurosci 1996, 14:399-408.

15. Lai JC, White BK, Buerstatte CR, Haddad GG, Novotny EJ Jr, Behar KL: Chronic hypoxia in development selectively alters the activities of key enzymes of glucose oxidative metabolism in brain regions. Neurochem Res 2003, 28:933-940.

16. Fagel DM, Ganat Y, Cheng E, Silbereis J, Ohkubo Y, Ment LR, Vaccarino FM: Fgfr 1 is required for cortical regeneration and repair after perinatal hypoxia. J Neurosci 2009, 29:1202-1211.

17. Basuroy S, Bhattacharya S, Leffler CW, Parfenova H: Nox4 NADPH oxidase mediates oxidative stress and apoptosis caused by TNF-a in cerebral vascular endothelial cells. Am J Physiol Cell Physiol 2009, 296:C422-432.

18. Lu KT, Cheng NC, Wu CY, Yang YL: NKCC1-mediated traumatic brain injury-induced brain edema and neuron death via Raf/MEK/MAPK cascade. Crit Care Med 2008, 36:917-922.

19. Badaut J, Fukuda AM, Jullienne A, Petry KG: Aquaporin and brain diseases. Biochim Biophys Acta 2014, 1840:1554-1565.

20. Jiang $W$, Xiao $L$, Wang JC, Huang $Y G$, Zhang $X$ : Effects of nitric oxide on dentate gyrus cell proliferation after seizures induced by pentylenetrazol in the adult rat brain. Neurosci Lett 2004, 367:344-348.

21. Jones PA, Smith RA, Stone TW: Nitric oxide synthase inhibitors L-NAME and 7-nitroindazole protect rat hippocampus against kainate-induced excitotoxicity. Neurosci Lett 1998, 249:75-78.

22. Brand $M$, Bignami $A$ : The effects of chronic hypoxia on the neonatal and infantile brain. A neuropathological study of five premature infants with the respiratory distress syndrome treated by prolonged artificial ventilation. Brain 1969, 92:233-254.

23. Albrecht J, Smialek M: Effect of hypoxia, ischemia and carbon monoxide intoxication on in vivo protein synthesis in neuron and glia cell enriched fractions from rat brain. Acta Neuropathol 1975, 31:257-262.

24. Lo CP, Chen SY, Lee KW, Chen WL, Chen CY, Hsueh CJ, Huang GS: Brain injury after acute carbon monoxide poisoning: early and late complications. AJR Am J Roentgenol 2007, 189:W205-211.
25. Hall GH: Effects of nicotine and tobacco smoke on the electrical activity of the cerebral cortex and olfactory bulb. Br J Pharmacol 1970, 38:271-286.

26. Carloni S, Mazzoni E, Cimino M, De Simoni MG, Perego C, Scopa C, Balduin W: Simvastatin reduces caspase-3 activation and inflammatory markers induced by hypoxia-ischemia in the newborn rat. Neurobiol Dis 2006, 21:119-126.

27. Guo G, Bhat NR: Hypoxia/reoxygenation differentially modulates NF-KB activation and iNOS expression in astrocytes and microglia. Antioxid Redox Signal 2006, 8:911-918.

28. Kroll J, Waltenberger J: VEGF-A induces expression of eNOS and iNOS in endothelial cells via VEGF receptor-2 (KDR). Biochem Biophys Res Commun 1998, 252:743-746.

29. Hou HH, Hammock BD, Su KH, Morisseau C, Kou YR, Imaoka S, Oguro A, Shyue SK, Zhao JF, Lee TS: N-terminal domain of soluble epoxide hydrolase negatively regulates the VEGF-mediated activation of endothelial nitric oxide synthase. Cardiovasc Res 2012, 93:120-129.

30. Proescholdt MA, Heiss JD, Walbridge S, Mühlhauser J, Capogrossi MC, Oldfield EH, Merrill MJ: Vascular endothelial growth factor (VEGF) modulates vascular permeability and inflammation in rat brain. J Neuropathol Exp Neurol 1999, 58:613-627.

31. Bates DO, Harper $\mathrm{SJ}$ : Regulation of vascular permeability by vascular endothelial growth factors. Vascul Pharmacol 2002, 39:225-237.

32. Oubaha M, Gratton JP: Phosphorylation of endothelial nitric oxide synthase by atypical PKC contributes to angiopoietin-1-dependent inhibition of VEGF-induced endothelial permeability in vitro. Blood 2009, 114:3343-3351.

33. Janigro D, West GA, Nguyen TS, Winn HR: Regulation of blood-brain barrier endothelial cells by nitric oxide. Circ Res 1994, 75:528-538.

34. Fukumura D, Gohongi T, Kadambi A, Izumi Y, Ang J, Yun CO, Buerk DG, Huang PL, Jain RK: Predominant role of endothelial nitric oxide synthase in vascular endothelial growth factor-induced angiogenesis and vascular permeability. Proc Natl Acad Sci U S A 2001, 98:2604-2609.

35. de la Torre JC, Aliev G: Inhibition of vascular nitric oxide after rat chronic brain hypoperfusion: spatial memory and immunocytochemical changes. J Cereb Blood FlowMetab 2005, 25:663-672.

36. Nielsen S, Nagelhus EA, Amiry-Moghaddam M, Bourque C, Agre P, Ottersen OP: Specialized membrane domains for water transport in glial cells: high-resolution immunogold cytochemistry of aquaporin-4 in rat brain. J Neurolsci 1997, 17:171-180.

37. Manley GT, Fujimura M, Ma T, Noshita N, Filiz F, Bollen AW, Chan P, Verkman AS: Aquaporin-4 deletion in mice reduces brain edema after acute water intoxication and ischemic stroke. Nat Med 2000, 6:159-163.

38. Manley GT, Binder DK, Papadopoulos MC, Verkman AS: New insights into water transport and edema in the central nervous system from phenotype analysis of aquaporin-4 null mice. Neuroscience 2004, 129:983-991.

39. Kim JE, Ryu HJ, Yeo SI, Seo CH, Lee BC, Choi IG, Kim DS, Kang TC: Differential expressions of aquaporin subtypes in astroglia in the hippocampus of chronic epileptic rats. Neuroscience 2009, 163:781-789.

40. Sørbø JG, Moe SE, Holen T: Early upregulation in nasal epithelium and strong expression in olfactory bulb glomeruli suggest a role for aquaporin-4 in olfaction. FEBS Lett 2007, 581:4884-4890.

41. Nguyen M, Pace AJ, Koller BH: Mice lacking NKCC1 are protected from development of bacteremia and hypothermic sepsis secondary to bacterial pneumonia. J Exp Med 2007, 204:1383-1393.

42. Chen $\mathrm{H}$, Luo J, Kintner DB, Shull GE, Sun D: $\mathrm{Na}^{+}$-dependent chloride transporter (NKCC1)-null mice exhibit less gray and white matter damage after focal cerebral ischemia. J Cereb Blood Flow Metab 2005, 25:54-66.

43. Win-Shwe TT, Mitsushima D, Yamamoto S, Fujitani Y, Funabashi T, Hirano S, Fujimaki $\mathrm{H}$ : Extracellular glutamate level and NMDA receptor subunit expression in mouse olfactory bulb following nanoparticle-rich diesel exhaust exposure. Inhal Toxicol 2009, 21:828-836.

doi:10.1186/s12974-014-0176-5

Cite this article as: Zou et al:: Combustion smoke-induced inflammation in the olfactory bulb of adult rats. Journal of Neuroinflammation 2014 11:176. 